\title{
A voz ou a plenitude do texto. Performance oral, práticas de leitura e identidade literária no Ocidente medieval
}

The voice or the text completeness. Oral performance, reading practices and literary identity in the medieval West

\section{Carlos F. Clamote Carreto}

\section{OpenEdition}

\section{Journals}

\section{Edição electrónica}

URL: http://journals.openedition.org/medievalista/958

DOI: $10.4000 /$ medievalista.958

ISSN: 1646-740X

\section{Editora}

Instituto de Estudos Medievais - FCSH-UNL

\section{Refêrencia eletrónica}

Carlos F. Clamote Carreto, «A voz ou a plenitude do texto. Performance oral, práticas de leitura e identidade literária no Ocidente medieval », Medievalista [Online], 19 | 2016, posto online no dia 01 junho 2016, consultado o 10 dezembro 2020. URL : http://journals.openedition.org/medievalista/958 ; DOI : https://doi.org/10.4000/medievalista.958

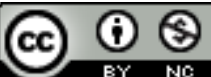

Mediavalista está licenciado com uma Licença Creative Commons - Atribuição-NãoComercial 4.0 Internacional. 
Título: A voz ou a plenitude do texto. Performance oral, práticas de leitura e identidade literária no Ocidente medieval I The voice or the text completeness. Oral performance, reading practices and literary identity in the medieval West Autor(es): Carlos F. Clamote Carreto Universidade:Universidade Aberta I Departamento de Humanidades Faculdade e Departamento / Unidade de Investigação: Instituto de Estudos de Literatura e Tradição (FCSH da UNL)

Código Postal: 1269-001 Lisboa

Cidade: Lisboa

País: Portugal

Contacto: carlos.carreto@uab.pt

Fonte: Medievalista [Em linha]. Dir. Bernardo Vasconcelos e Sousa. Lisboa: IEM.

Disponível em:

http://www2.fcsh.unl.pt/iem/medievalista/MEDIEVALISTA19/carreto1903.html ISSN: 1646-740X

Data recepção do artigo: 9 de Outubro de 2015

Data aceitação do artigo: 6 de Novembro de 2015

\section{Resumo}

Num célebre episódio relatado no livro VI, 3 das suas Confissões, Santo Agostinho manifesta a sua perturbação e perplexidade perante a atitude do seu mestre e amigo Ambrósio cujos olhos deambulam, em absoluto silêncio, pelas páginas de um manuscrito. Porquê este espanto que a crítica se apressou a interpretar como uma inequívoca prova de que a Alta Idade Média, herdeira dos modelos da Antiguidade Clássica, cultivou essencialmente a leitura em voz alta, ao invés da Baixa Idade Média (essencialmente a partir dos séculos XI-XIII) que teria inventado a leitura silenciosa, prática que o progressivo alargamento das comunidades textuais (Brian Stock) viria acentuar de forma irreversível? Partindo do testemunho privilegiado da literatura francesa medieval (mas não só), estas reflexões visam questionar a conceção 
evolucionista e cognitiva da leitura recentrando a problemática na irredutível tensão que tem em parte caracterizado a cultura ocidental - entre a letra e a voz, entre uma idealização da escrita erguida à esfera mágica do Sagrado (ou da Lei) que coloca a performance oral sob o signo da efabulação corruptora, e uma longa tradição que, de Platão a Hegel, assimila o logocentrismo a um fonocentristo em que a escrita, significante do significante (Jacques Derrida) não passa de uma cristalização redutora da voz da qual emana a totalidade do ser e a plenitude da palavra.

Palavras-chave: Literatura Francesa Medieval; Tradição oral e cultura escrita; História da leitura; História do Livro.

\section{Abstract}

In a famous episode described in his Confessions (Book VI, 3), St. Augustine expresses his confusion and perplexity to the attitude of his master and friend Ambrose whose eyes roam, in absolute silence, through the pages of a manuscript. How can we explain this astonishment that modern criticism has interpreted as a clear evidence that High Middle Ages, following the models of Classical Antiquity, mainly developed the reading aloud, rather than the Early Middle Ages that had invented silent reading?

Through the privileged perspective of French Medieval Literature (but not only), these reflections aim to question the evolutionary and cognitive conception of the history of reading refocusing the problem in the irreducible tension - which has partly characterized Western culture - between the letter and the voice, between an idealization of the writing elevated into the magic sphere of the Sacred (or the Law) which places the oral performance under the sign of a corrupted fabula, and a long tradition that, from Plato to Hegel, assimilates logocentrism and phonocentrism. In this perspective, writing, a signifier of a signifier (Jacques Derrida), is nothing but a tarnished crystallization of the voice which emanates the entire Being and the unity of the word.

Keywords: French Medieval Literature; Oral and written culture; History of reading; History of book. 


\title{
A voz ou a plenitude do texto. Performance oral, práticas de leitura e identidade literária no Ocidente medieval ${ }^{1}$
}

\section{Carlos F. Clamote Carreto}

La voix gîte dans le silence du corps, comme fit le corps dans sa matrice (...). Parle-t-elle, que résonne en son creux l'écho de ce désert d'avant la rupture, d'où sourdent la vie et la paix, la mort et la folie. Le souffle de la voix est créateur (...). Chaque syllabe est souffle, rythmée par le battement du sang; et l'énergie de le ce souffle, avec l'optimisme de la matière, convertit la question en annonce, la mémoire en prophétie, dissimule les marques de ce qui s'est perdu et affecte irrémédiablement le langage et le temps. C'est pourquoi la voix est parole sans paroles, épurée, filet vocale qui fragilement nous relie à l'Unique.

Paul ZUMTHOR, Introduction à la poésie orale, p. 11 e $13^{2}$.

\author{
Mesire Yvains el vergier entre \\ Et aprés lui toute sa route; \\ Apuyé voit deseur son coute \\ Un preudomme qui se gesoit \\ Seur.i. drap de soie, et lisoit \\ Une puchele devant li \\ En un rommans, ne sai de cui. \\ Et pour le rommans escouter \\ S'i estoit venue acouter \\ Une dame, et estoit sa mere.
}

Chrétien de TROYES, Yvain ou le Chevalier au Lion, v. 5356-65³.

\footnotetext{
${ }^{1}$ Este artigo retoma as reflexões da conferência inaugural apresentada a 17 de abril de 2015 na Biblioteca Regional do Funchal no âmbito do $I I I^{\circ}$ Encontro Literário de Leitura em Voz Alta organizado pela associação Contigo Teatro com o apoio da Direção Regional de Educação.

2 Paris: Seuil, 1983. Sobre a dimensão mágica e oracular da voz na poesia oral da Idade Média, ver também BOUTET, D. - “L'oral et l'ecrit dans la France médiévale". in F. LESTRINGANT; M. ZINK (dir.) - Histoire de la France littéraire. Naissances, Renaissances: Moyen Âge-XVI $I^{e}$ siècle. Paris: PUF, 2006, pp. 193-212.
}

Medievalista online № 19| Janeiro - Junho 2016 (C) IEM - Instituto de Estudos Medievais 3 


\section{A letra e a voz ${ }^{4}$ : paradoxos, equívocos e tensões}

No livro VI, 3 das suas Confissões (compostas entre 397 et 401), Santo Agostinho relata um estranho episódio 5 . Sentindo a necessidade de se aconselhar com o seu mestre e amigo Ambrósio, eis que entra um dia no seu quarto e surpreende-se com um hábito que, para nós, leitores do século XXI, deixou de causar qualquer estranheza ou perplexidade. Os olhos de Ambrósio deambulam, silenciosos, pelas páginas de um manuscrito ao mesmo tempo que o seu intelecto penetra as profundezas do sentido, totalmente alheio ao mundo que o rodeia. Porquê este espanto que a crítica se apressou a interpretar como uma inequívoca prova de que a Alta Idade Média, herdeira dos modelos da Antiguidade Clássica, cultivou essencialmente a leitura em voz alta, ao invés da Baixa Idade Média (essencialmente a partir dos séculos XI-XIII) que teria inventado a leitura silenciosa, prática que o progressivo alargamento das "comunidades de leitores" $"$, cada vez mais heterogéneas com o crescimento das cidades, o desenvolvimento da cultura mercantil, a expansão das escolas urbanas e a consecutiva multiplicação dos letrados e, mais tarde, o advento da impressa e de uma cultura marcadamente visual, viria acentuar de forma irreversível? Sobre esta interpretação se construíram pressupostos (ou estereótipos) culturais - e mesmo pedagógicos - que ainda hoje tenazmente resistem e aos quais teremos a oportunidade de regressar. Mas voltemos à pergunta inicial. O que é que, na atitude de Ambrósio, deixou Santo Agostinho tão perplexo ao ponto de se sentir impelido a justificar um hábito que, seja qual for a sua intenção, só poderia ser virtuoso porque praticado, conclui ele, por um homem virtuoso ("Quolibet tamen animo id ageret, bono utique ille vir agebat")? Uma leitura atenta do texto revela que o que está aqui no centro do escândalo é o silêncio total (tacite) no qual se processa a leitura e não a expectável leitura em voz baixa

\footnotetext{
${ }^{3}$ Ed. e trad. de D. HUE. in Chrétien de Troyes. Romans. Paris: Librairie Générale Française, 1994, p. 887.

${ }^{4}$ Retomamos o título da já clássica, embora sempre pertinente, obra de ZUMTHOR, P. - La Lettre et la voix. De la «littérature» médiévale. Paris: Seuil, 1987.

${ }^{5}$ Ed. bilingue (Latim/Francês) de P. de Labriolle. Vol. 1. Paris: Les Belles Lettres, 1977.

${ }^{6}$ CHARTIER, R - "Communautés de lecteurs". in Culture écrite et société. L'ordre des livres (XIV XVIII siècle). Paris: Albin Michel, 1996, pp. 133-154. Para os aspetos metodológicos importante a ter em consideração numa reflexão sobre o fenómenos histórico e cultural da leitura, ver KRAUS, D. "Appropriation et pratiques de la lecture", Labyrinthe [Em linha]. 3 (1999) [Consultado a 24 de março de 2015]. Disponível em www.http://labyrinthe.revues.org/56.
} 
(também designada de murmúrio ou ruminatio) como técnica (monástica e não só) de suporte à meditação, interiorização e memorização da palavra divina ou consagrada. $\mathrm{Na}$ verdade, não será também esse modo de leitura que ainda hoje qualificamos de silencioso uma leitura predominantemente sussurrada, quase inaudível apesar de levemente vocalizada, situada nos limiares entre a articulação das palavras e um sopro contínuo que confunde os sons e impede a sua segmentação/apreensão pelo ouvido? Quantas vezes não fomos surpreendidos (em nós ou nos outros) por esta prática solitária, lúdica e cognitiva da leitura, cujo ritmo lancinante a assemelha a uma ladainha encantatória, a um mantra ou a uma oração? Mas em Ambrósio, a voz e a língua estão em repouso absoluto ("vox autem et lingua quiescebant"). Agostinho explica: talvez o silêncio fosse, para o mestre, uma forma de descansar, isolando-se, no prazer da leitura, dos tumultos de uma atividade particularmente exigente? Talvez fosse, por outro lado, uma maneira de evitar que o texto no qual está a meditar viesse a ser escutado por um ouvido atento que nele logo descobriria alguma passagem obscura ou difícil, obrigando então Ambrósio a interromper o seu estudo individual e a substituir o silêncio da mediação por um atividade hermenêutica ruidosa, longa, penosa e, provavelmente, prematura? Ou, quem sabe, talvez Ambrósio quisesse tão-somente poupar a sua frágil e quebradiça voz ("causa servandae vocis, quae illi facillime obtundebatur poterat esse justior tacite legendi”)? Seja como for, esta confissão revela dois aspetos fulcrais no âmbito de uma antropologia da leitura. Por um lado, a natureza ameaçadora, quase ilícita ou transgressiva, da leitura silenciosa, como se na espessura opaca do silêncio se inscrevesse uma intenção ínvia, um não-dito incontrolável, uma ambiguidade inquietante. $\mathrm{Na}$ realidade, por mais que a tradição mística e monástica valorize o silêncio contemplativo, a sua relação com o livro e a escrita parece contradizer um dos fundamentos antropológicos da civilização medieval que assenta (e assentará cada vez mais, nomeadamente com o advento das ordens mendicantes e pregadoras dos séculos XII e XIII) numa teologia do Verbo Incarnado, ou seja, numa teologia da Revelação que passa por tornar fecunda e luminosa a palavra que Deus semeou na letra das Escrituras, tanto através atividade exegética ou da pregação em ambiente urbano, como através da prática da leitura em voz alta ou da atividade poética, e por uma unânime rejeição do 
silêncio como forma de avareza espiritual que condena a palavra à esterilidade de uma letra morta ${ }^{7}$. A leitura silenciosa, cortada do mundo, solitária, reenvia para as esferas da intimidade, da subjetividade, da interioridade secreta e da privacidade que a Alta Idade

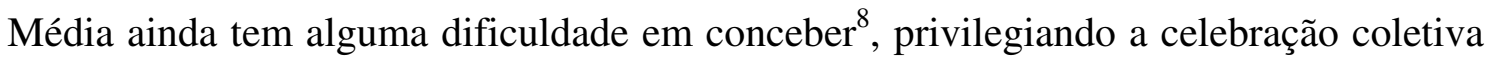
e a apropriação/consumação do texto (voltaremos a esta importante questão) como ato eminentemente comunicativo, seja em contexto litúrgico, pastoral ou pedagógico. Por outro lado, o episódio contado pelo Bispo de Hipona leva-nos a relativizar a oposição leitura em voz alta $v s$ leitura silenciosa como se esta última fosse a consequência lógica e o apanágio da civilização ocidental moderna na sequência da revolução de Gutenberg que conduz à industrialização do livro e à substituição de uma cultura marcadamente oral e simbólica por uma civilização dominada pelo "homem tipográfico", esquizofrenicamente cortado do mundo, de que falava McLuhan na sua célebre Galáxia de Gutenberg $(1962)^{9}$. E esta relativização histórica e cultural convida-nos igualmente a abandonar uma perspetiva cognitivista e evolucionista da leitura baseada em vários pressupostos (ou equívocos) teóricos e metodológicos potencialmente falaciosos ${ }^{10}$ para adotarmos uma perspetiva mais pragmática baseada nas funções inerentes a cada modo de leitura.

\footnotetext{
7 "Littera occidit, spiritus autem vivificat". Esta célebre advertência de São Paulo na sua Epístola aos Coríntios (2 Coríntios 3:5-6) foi amplamente glosada por Santo Agostinho (De Doctrina Christiana, III, VI-X) no intuito de legitimar a prática exegética como atividade (con)sagrada, uma vez que liberta o sentido aprisionado na letra e se afasta assim de uma postura considerada idolatra perante o significante textual. Muitos prólogos de narrativas ficcionais dos séculos XII-XIII exploram esta imagem da palavra como semente ou dom que o poeta tem por dever ético e moral fazer frutificar. Veja-se, por exemplo, o prólogo dos Lais de Marie de France ou o que inaugura o último romance de Chrétien de Troyes - Le Conte du Graal - nos quais se vislumbra uma translatio da Parábola dos Talentos (Mateus 25:14-30 e Lucas 19:17-27) em que o verbo poético se equipara sub-repticiamente ao Verbo divino. Sobre esta questão, vejam-se as nossas reflexões em 'Contez vous qui savez de nombre'. Imaginaire marchand et économie du récit au Moyen Âge. Paris: Champion, 2014, pp. 99-128.

${ }^{8}$ RUDDER, O. de - "Pour une histoire de la lecture". Médiévales. 3 (1983) p. 97-110; BEDOS-REZAK, B. M. e IOGNA-PRAT, D. - L'Individu aи Moyen Age. Paris: Aubier, 2005.

${ }^{9}$ Sobre esta questão, ver também a obra clássica de EISENSTEIN, E. - The Printing Press as Agent of Change. 2 vols. Cambridge: Cambridge University Press, 1979.

${ }^{10}$ Ver, neste sentido, os importantes trabalhos de reformulação metodológica que Hélène HAUG tem vindo a desenvolver. Na sua tese de Doutoramento apresentada em 2013 à Universidade de Lovaina (Fonctions et pratiques de la lecture à la fin du Moyen Âge. Approche sociolittéraire du discours sur la lecture en milieu curial d'après les sources narratives françaises et bourguignonnes [1360-1480]), considera a passagem da leitura oralizada à leitura silenciosa um autêntico mito construído pela crítica com base em pressupostos ideológicos e metodológicos questionáveis, propondo assim a sua substituição, numa perspetiva pragmática e funcional mais flexível e adequada para traduzir a complexidade inerente a cada contexto histórico e literário, pelo binómio "leitura para si" vs "leitura para o outro".
} 
Com efeito, a relação entre escrita e oralidade na civilização ocidental deve ser abordada no prisma da plena coexistência de dois sistemas de representação que se complementam e não, como nas sociedades ditas "tradicionais" analisadas por Jack Goody, entre outros estudiosos ${ }^{11}$, na perspetiva da passagem de uma cultura para a outra com óbvias implicações na organização da sociedade e do poder, na visão do mundo partilhada pelo homens e na própria conceção (tanto social como cognitiva), construção e transmissão do Conhecimento. Tanto quanto nos é possível saber (ou supor), de acordo com as fontes disponíveis e tendo em consideração a intransponível distância que nos separa do passado e a forma concreta como cada época e cada comunidade de leitores viveu, sentiu e praticou a leitura, o hábito de ler em silêncio (tacite legere) já existia no mundo antigo (é referido, por exemplo, no Sermonum liber secundus ou Sátira II de Horácio - 30 a.C.) que o transmite à Alta Idade Média. No prefácio às suas Institutiones divinarum et saecularium litterarum (543-555), Cassiodoro ${ }^{12}$ distingue a "sedula lectio" - operação intelectual consistindo numa apropriação silenciosa do texto com vista à colação, ao ensino ou ao comentário - da leitura segunda, articulada pela voz (pronuntiata) e também designada de "simplicissima lectio", uma vez que era praticada por confrades menos cultos (ou menos importantes na hierarquia monástica) em contexto essencialmente litúrgico, ou seja, comunitário. Também a literatura ficcional nos oferece ecos desta prática. Numa canção de gesta composta no século XIV, Tristan de Nanteuil que recupera, na sua parte final, a tradição textual da Vida de Santo Egídio, vemos um anjo entregar, durante a celebração do ofício a que assiste Carlos Magno e a sua corte, uma mensagem a Egídio na qual é revelado o pecado secreto do Imperador (a relação incestuosa com a sua irmã da qual nasceu o famoso herói épico Roland). Tendo em conta o contexto público em que decorre a cena e a natureza inconfessável do crime ${ }^{13}$, nenhuma sílaba, nenhum sussurro, nenhuma palavra

${ }^{11}$ GOODY, J. - The Power of the Written Tradition. Washington/ Londres: Smithsonian Institution Press, 2000; MANGUEL, A. - Une histoire de la lecture. Paris: Actes du Sud, 1998. Para uma aplicação à Idade Média, ver ONG, W. - Orality and Literacy: The Technologizing of the World. Londres/Nova York: Methuen, 1982; SAENGER, P. - "Silent Reading: Its Impact one Late Medieval Script and Society". Viator. 13 (1982) pp. 367-414.

${ }^{12}$ Apud A. PETRUCCI, A. - "Lire au Moyen Âge". in Mélange de l'École française de Rome. T. 96. 2 (1984) p. 604.

${ }^{13}$ Num interessante artigo intitulado "Pecados secretos", inicialmente publicado em 2000 no no 5 da revista Sigila. Revue transdisciplinaire franco-portugaise sur le secret e recentemente reeditado na obra Poderes invisíveis. O imaginário medieval com o título "Satanás, o Acusador" (pp. 241-265), José

Medievalista online N 19| Janeiro - Junho 2016 (C) IEM - Instituto de Estudos Medievais 7 
comprometedora poderia naturalmente escapar dos lábios de Egídio, que lê, rápida e em absoluto silêncio, a missiva ${ }^{14}$.

Sensivelmente na mesma altura em que Cassiodoro escrevia as suas Institutiones, surgia igualmente um outro texto de particular relevância do ponto de vista cultural no qual a problemática da leitura ganhava singular destaque por se situar num contexto dominado pelo imperativo do silêncio. Com efeito, na sua procura de refrear a palavra vã, ociosa ou nefasta através da prática da taciturnidade (capítulo VI) e da leitura, A Regra de São Bento $^{15}$ vai procurar circunscrever os tempos e os lugares adequados a cada modalidade de leitura. A leitura em voz alta, presença obrigatória durante as refeições, contrastando com o silêncio absoluto que os monges devem observar nessa altura (cap. XXXVIII), marca ainda o calendário litúrico, ritmando todos os ciclos da vida quotidiana em alternância com os restantes trabalhos manuais ou compromissos religiosos. Aos domingos e durante a Quaresma (tempo em qua cada monge recebe um livro da biblioteca que terá de ler até ao fim), esta atividade torna-se mais intensa (cap. XLVIII),

Mattoso analisa longamente o que considera ser uma atitude mental bastante difundida face aos crimes nefanda e aos pecados ocultos em geral que consiste em dissimular ou manter na esfera estritamente privada delitos graves (como o incesto ou o infanticídio) cuja divulgação seria vista como particularmente ameaçadora para a ordem social. As fontes heterogéneas, tanto do ponto de vista genológico como pragmático (narrativas de cavalaria, Cantigas de Santa Maria de Afonso X, Milagres, Vidas de Santos, Livros de Confissão e Penitenciais, Sermões e exempla), que José Mattoso percorre dão ainda conta da progressiva transformação cultural e ideológica que se opera a partir de meados do século XII com a propaganda em torno da obrigatoriedade da confissão auricular. Começando por se instituir como mediadora incontornável entre o homem e Deus, o silêncio e a palavra - cuja utilização está, de resto, sujeita a uma disciplina cada vez mais complexa e exigente), a instituição eclesiástica apropria-se da personagem ambígua, embora extremamente eficaz, do diabo - esse grande delator de segredos que se projeta exemplarmente na paradoxal figura de Merlim na literatura arturiana - e adquire progressivamente o monopólio sobre os pecados ocultos que transforma no "mais poderoso instrumento de dominação que jamais houve sobre a Terra" (J. MATTOSO - "Satanás, o Acusador". in Poderes invisível. O imaginário medieval. Lisboa: Círculo de Leitores, 2013, p. 261).

14 "Ung ange especial qui molt iert seignoris/ Qui par-dessus l'aitel c'est devant Gilles mis,/ Et lui tendi ung bref, et saint Gilles l'a prins (...)./ Saint Gilles leut le bref et vit par les escrips/ Que Charles est pecherres et a Deu ennemis (...)./ Le preudons lest le bref, a Dieu servir c'est mis" (Ed. K. V. SINCLAIR. Assen: Van Gorcum \& Comp., 1971, v. 21661-21672). Poder-se-iam multiplicar os exemplos: na Espinette amoureuse (v. 694-701 da ed. A. FOURRIER. Paris: Klincksieck, 1972), o poeta e cronista Jean Froissard (século XIV) descreve a emoção que sentiu perante a visão de uma jovem que lia para si em voz baixa. Na Chanson des Saisnes de Jehan Bodel (século XIII), vemos um capelão ler silenciosamente para si uma missiva antes de partilhar o seu conteúdo com o príncipe Salomão (v. 593597 da ed. A. BRASSEUR. Genebra: Droz, 1989, t. 1). Numa outra canção de gesta anónima, Renaut de Montauban (finais do séc. XIII), um emissário entrega a Carlos Magno uma carta esperando que este lha devolva para a ler em voz alta. Mas eis que o imperador se apodera da missa e percorre o seu conteúdo em silêncio, o narrador descrevendo as expressões que aparecendo no seu rosto (v. 6227-6241 da ed. J. THOMAS. Genebra: Droz, 1989).

${ }^{15}$ Ed. bilingue (Latim/Francês) de H. ROCHAIS. Paris: Desclée de Brouwer, 1997. 
a leitura adquirindo uma clara dimensão simultaneamente edificante e purificadora (terapêutica, dir-se-ia hoje). A Regra autoriza os monges a prolongarem a leitura comunitária na solidão das suas celas durante a noite, desde que essa prática, presumivelmente vocalizada, murmurante, não incomode os outros. Permito-me ainda destacar duas funções particularmente significativas assignadas à leitura em voz alta neste texto: o seu papel no acolhimento dos hóspedes, com um intuito moral e pedagógico, já que permite a interiorização da palavra ouvida durante a oração que precede este tempo de leitura da Lei, mas também com uma dimensão quase ontológica, a leitura em voz alta conduzindo a uma transformação identitária: o estrangeiro torna-se num semelhante, o desconhecido num ser familiar, a distância em proximidade, a leitura em voz alta, necessariamente integradora do ouvinte, exorcizando assim a componente ameaçadora ligada à alteridade. $O$ segundo aspeto relevante diz respeito às competências de leitura. A propósito da forma como deve ser escolhido o leitor semanal, a Regra refere claramente que nem todos os monges podem assumir esta função, mas apenas aqueles "cuja leitura é proveitosa aos que os ouvem” (cap. XXXVIII). Donde se depreende que a técnica da leitura em voz alta é uma arte particularmente difícil de dominar que não implica apenas uma mera decifração e vocalização dos significantes literais.

Este exemplo permite-nos abordar uma outra questão essencial tanto do ponto de vista teórico como metodológico: da impossibilidade de falar do fenómeno da leitura sem ter em consideração a história dos suportes materiais da escrita. Ora, durante toda a alta Idade Média (ou seja, até ao século XI sensivelmente), verifica-se que escrita e leitura funcionam como dois sistemas distintos que não estão forçosamente destinados a interagir um com o outro. Na altura em que São Bento escreve, está em uso a escrita contínua em que as palavras se ligam umas às outras, sem sinais de pontuação (ou muito raramente e de forma, por vezes, aleatória), o traço ininterrupto e compacto da tinta negra alternando, na página do manuscrito, com as linhas deixadas em branco. Esta página escrita do códex é, por conseguinte, uma página silenciosa que o leitor, sob orientação do mestre, deve ler pausada e inteligentemente, ou seja, na aceção etimológica desta última palavra, aprendendo a separar os segmentos morfológicos, lexicais e sintáticos uns dos outros, e interpretar o sentido, a entoação (afirmativa, exclamativa, interrogativa) e o ritmo dos enunciados gramaticais. Ontem como hoje, é 
impensável existir leitura em voz alta sem esta etapa prévia. A leitura situa-se assim numa dimensão exterior ao texto enquanto que no livro atual, seja ele manuscrito, digital, datilografado ou impresso, já se encontra (à exceção de experiências poéticas que, de Apollinaire a José Saramago ou António Lobo Antunes, voltam a colocar o leitor perante o desafio de reconstruir um sentido para o texto) de certo modo balizada e orientada por uma disposição específica da escrita no espaço da página e por uma multiplicidade de sinais gráficos que ritmam os enunciados e norteiam o sentido. A uma população maioritariamente analfabeta durante mais de mil anos ${ }^{16}$, correspondem naturalmente índices de leitura extremamente baixos. O livro destina-se a conservar e a perpetuar a memória de uma palavra sagrada ou autoral, não para ser lido, existindo inclusive (mesmo em centros monástico particularmente ativos na produção de manuscritos como São Galo, por exemplo) muitos escribas (ou copistas) iletrados ou semianalfabetos ${ }^{17}$. As condições materiais que envolviam o ato de leitura também não eram as mais propícias ao desenvolvimento desta atividade: os livros eram guardados em lugares de difícil acesso (as primeiras bibliotecas como espaço amplos e iluminados destinados especificamente à leitura - seja ela pessoal ou coletiva - apenas surgem no século XIII com as Ordens Mendicantes e a Escolástica) e lidos em condições de luminosidade deficiente (celas, refeitório, claustros) tornando-a provavelmente numa prática que, para além de tecnicamente difícil já que implicava balbuciar lentamente quase sílaba e segmento do texto para tatear e reconstruir passo a passo o seu sentido, era extremamente penosa, árdua e, por conseguinte, rara. Poder-se-á considerar assim que, até ao século XI, época em que surgem as primeiras alterações gráficas destinadas a facilitar esta operação (utilização do traço para sinalizar uma palavra cortada que continua na linha seguinte; utilização do $S$ maiúsculo em final de palavra, etc.), a leitura não passa de um epifenómeno.

Os séculos XII e XIII inauguram o tempo de uma nova aliança entre escrita e leitura: lêse para escrever (glosas, comentários exegéticos) à margem dos textos, a escrita

${ }^{16}$ Recordemos que ainda no século XVII se estima que apenas um homem em três e uma mulher em cinco conseguem escrever o seu nome. Ver a excelente síntese de C. BIET sobre as relações entre oralidade e escrita no período clássico (séculos XVII-XVIII) - "L'oral et l'écrit". in DARMON, J.-Ch.; DELON, M. - Histoire de la France littéraire. Classicismes : XVII -XVIII siècle. Paris: PUF, 2006, pp. 409-434.

${ }^{17}$ Ver PETRUCCI, A. - "Lire...”, art. cit., p. 607. 
reorganizando-se progressivamente no espaço da página para facilitar uma mais rápida apropriação do texto. Por motivos sobejamente conhecidos que começam a desenhar-se desde a época das reformas carolíngias (desenvolvimento de uma burocracia assente no poder da escrita; criação das universidades e das escolas laicas; crescimento das cidades e de uma cultura urbana que vê multiplicarem-se os profissionais da escrita e da leitura - professores, juristas, notários, teólogos, mercadores, etc. - e que exige, por conseguinte novas estratégias de disseminação da palavra divina no coração das cidades), a produção e a circulação dos livros aumenta consideravelmente durante esse período, acompanhando-se de diversas inovações técnicas que alteram, em profundidade, a relação com o livro. No período escolástico-universitário, este adquire uma dimensão maior (por oposição ao livro de pequeno formato dos séculos anteriores), tornando-se mais pesado e difícil de manejar, o que incentiva a uma leitura em posição estática (e hierática) na qual o livro ocupa uma posição central e tendencialmente fixa. Esta transformação favorecia, por conseguinte, todo um sistema de ensino - cujos reflexos ainda se faziam sentir até há bem pouco tempo nas universidades europeias assente na leitura magistral. Por oposição à ruminatio meditativa e contemplativa da cultura monástica, a leitura magistral une o mestre aos discípulos numa comunidade coesa unida através da voz que vai dividindo (esta é uma operação crucial à qual todos os tratados medievais que se debruçam sobre a leitura dão particular ênfase ${ }^{18}$, uma vez que traduz a passagem da adequada articulação entre a materialidade inerte e confusa da letra para a dimensão espiritual e fecundante da interpretação que conduz à emergência do sentido) e comentando os textos, ajudando assim a fixar simultaneamente um cânone textual, práticas de leitura e modelos exegéticos. Durante este período, a escrita passa a organizar-se em duas colunas por página, o que permite uma melhor e mais eficiente apreensão visual do texto (ou de partes inteiras do texto); texto cujas articulações são, por sua vez, postas em destaque através da sua divisão por capítulos e subcapítulos devidamente rubricados e identificados por letras capitais de tamanho diferente e por

\footnotetext{
${ }^{18}$ Veja-se o penúltimo capítulo do famoso tratado de Hugo de São Vítor, o Didascalicon ou "arte de ler" (VI, 12), que apresenta as formas de ler do seguinte modo: "Modus legendi in dividendo constat. Divisio fit et partitione et investigatione. Partiendo dividimus quando ea quae confusa sunt distinguimus. [809B] Investigando dividimus quando ea quae occulta sunt reseramus" (Hugonis de Sancto Victore Didascalicon de Studio Legendi, ed. crítica de Ch. Henry BUTTIMER. Washington: The Catholic University Press, 1939). Trad. francesa com introdução e notas de M. LEMOINE. L'Art de lire. Didascalicon. Paris: Cerf, 1991.
} 
vezes subtilmente ornamentadas. Graças à introdução de um complexo sistema de abreviaturas, a leitura torna-se muito mais ágil e veloz e o livro mais facilmente consultado. Os sinais de pontuação, quando emergem, têm uma função rítmica e musical (inicialmente, são, de resto, os mesmos sinais que são utilizados em ambos os sistemas de notação), indicando ao leitor os lugares e tempos em que deve elevar ou baixar a voz, fazer pausas. A todas estas inovações, que permitem dominar o tempo da leitura através de uma profunda reorganização espacial da escrita, acrescente-se a progressiva substituição do papiro pelo papel, menos dispendioso, a partir dos séculos XIII e XIV, e a introdução de elementos que favorecem a leitura seletiva: índices remissivos, tábuas alfabéticas, marcadores e tabulações, entre outros aspetos, que rompem progressivamente com uma certa linearidade textual, fazendo do texto um verdadeiro hipertexto que se pode percorrer em várias direções em função de necessidades específicas. Mais ordenado, hierarquizado e balizado, o livro torna-se também num objeto, estética e semioticamente, mais complexo ${ }^{19}$, à palavra escrita juntando-se um rico e diversificado programa iconográfico (tanto mais rico e diversificado, claro está, quanto mais luxuoso for o manuscrito) que engendra intrincadas e híbridas relações entre escrita e imagem que ajudam a ritmar a leitura ao mesmo tempo que complexificam os níveis de interpretação. Como vemos, a nossa conceção e o nosso imaginário de livro nascem definitivamente no século XII, período durante o qual se consuma o radical afastamento entre o códex (emblema do saber e da auctoritas relacionados com a tradição escrita) e o volumen (o rolo de papiro) cuja imagem, cada vez mais devoluta e frágil, reenvia para o registo pragmático (contabilidade, auxiliares de memória), a performance oral (poesia lírica ou teatro) e uma conceção irreversível e linear do tempo (genealogia, crónicas, etc.) ${ }^{20}$.

${ }^{19}$ Ver as nossa reflexões em "Topique et utopie du livre au Moyen Âge: le texte (im)possible". in MILON, A. e PERELMAN, M. (dir.) - Le Livre et ses espaces. Paris: Presses Universitaires de Paris 10, 2007, pp. 35-61.

${ }^{20}$ Sobre estas questões, ver VANDENDORPE, C. - Du papyrus à l'hypertexte. Essai sur les mutations du texte et de la lecture. Paris: La Découverte, 1999; HASENOHR, G. - "Le livre manuscrit". in LESTRINGANT, M.; ZINK, M. (dir.) - Histoire..., pp. 151-173. 
Nos séculos XIII e XIV, com o crescimento de uma "comunidade textual"21 cada vez mais vasta e heterogénea (público laico-burguês de mercadores, artesãos, artistas, notários, etc.) associado ao desenvolvimento de uma importante produção literária em língua vernácula (nomeadamente em França, Inglaterra, Alemanha, Itália e países escandinavos), multiplicam-se os livros de médio formato com escrita cursiva não tipificada e adotam-se hábitos de leitura familiar em círculos mais restritos (casa, comércio, etc.) que contrastam com os espaços abertos e luxuosos (jardins, salões, parques, etc.) da leitura aristocrática que se insere numa "paideia mais complexa e orgânica que integra as artes da conversação, da música e do corpo",22 e na qual as mulheres (por oposição aos meios mercantis e essencialmente escolásticouniversitários) desempenham um papel importante ${ }^{23}$. Com o Renascimento italiano dos séculos XIV-XV marcado por um profundo desejo de regresso ao estudo dos textos clássicos e ao próprio formato do livro da época romana ${ }^{24}$, a mancha textual volta a ficar mais densa e compacta, convidando a uma leitura mais lenta, pausada e solitária; mais intimista e privada dirão alguns ${ }^{25}$. O século XV e o advento da imprensa são

${ }^{21}$ Conceito retirado de B. STOCK - The Implications of Literacy. Written Language and Models of Interpretation in the Eleventh and Twelfth Centuries. Princeton: Princeton University, 1983, pp. 88-240.

${ }^{22}$ PETRUCCI, A. - "Lire...", art. cit., p. 613.

${ }^{23}$ GREEN, D. H. - Women Readers in the Middle Ages. Cambridge: Cambridge University Press, 2007. Recorde-se a célebre passagem do Inferno de Dante (v. 127-138) em que Paolo e Francesca leem em conjunto um livro que conta o desafortunado amor de Lancelot e da rainha Guenièvre.

${ }^{24}$ Regressa-se assim, com frequência, ao livro de morfologia mais reduzida, não raras vezes retangular, do qual desaparecem totalmente as abreviaturas bem como o aparato constituídas pelas glosas e comentários da escolástica, e no qual a minúscula carolina e a maiúscula de românico vêm substituir a letra gótica (PETRUCCI, A. - "Lire...", art. cit., pp. 613-615).

${ }^{25}$ Não podemos deixar de referir, neste contexto, um género singular em plena expansão em todo o Ocidente cristão nos XIV e XV: os Livros de Horas. Adotando novas soluções iconográficas e ornamentais mais adequadas à expressão da devoção privada dos leigos, os Livros de Horas espelham certamente novos hábitos e novas sensibilidades face à leitura cuja análise sistemática e aprofundada, com as suas implicações tanto do ponto vista da história do livro como das mentalidades, ainda está, em grande parte, por fazer. Sejam eles lidos em silêncio ou em voz baixa, em total solidão ou na presença de grupos restritos, emergem através dos Livros de Horas zonas claro-escuras de privacidade e de individualidade (muitas destas obras eram personalizadas em função dos comendatários) onde ganha particular relevo a aliança entre a imagem e o texto e a formação de um imaginário feminino da leitura e do livro desenvolvido em torno do culto mariano. Esta fascinante questão deu aliás lugar, em 2014, ao projeto conjunto (IEM, BNP, CEH e Departamento de Conservação e Restauro da Universidade Nova de Lisboa) Livros de Horas. O imaginário da devoção privada que se materializou numa exposição na BNP de 14 de novembro a 15 de e num colóquio internacional (13 e 14 de fevereiro) onde a problemática do livro, da leitura e das suas representações foi amplamente discutida. Como afirma Ana LEMOS ("O Livro de Horas de D. Duarte. Estado da arte, percurso e caracterização de um manuscrito". in BARREIRA, C. e METELO DE SEIXAS, M. (dir.) - D. Duarte e a sua época: arte, cultura, poder e espiritualidade. Lisboa: FCSH/IEM, 2014, p. 211), o Livro de Horas de D. Duarte reflete exemplarmente, além de um "fascínio pessoal" da dinastia de Avis, uma "consciência do livro como imagem da cultura e do poder no

Medievalista online $N^{\circ} 19 \mid$ Janeiro - Junho 2016 (C) IEM - Instituto de Estudos Medievais 13 
naturalmente decisivos na consolidação destes novos modos e práticas de leitura na Europa ocidental, nomeadamente através da criação das "bibliotecas de Estado" e do aparecimento do livro de leitura laico de pequeno formato que dará origem ao livro de bolso. O primado da apreensão visual do texto não implica contudo o silenciar da literatura $^{26}$. Sabemos quão o género novelístico inaugurado pela Decâmeron de Bocácio e, na sua filiação direta, o Heptaméron de Margarite de Navarre, é tributário da transmissão oral (mesmo que inteiramente simulada ou fictícia) e do prazer de contar que ajuda um grupo de personagens díspares a sobreviver a um universo em decomposição (peste, desolação), reconfigurando assim, através da ficção vocalizada, a sua própria identidade e visão do mundo. No prólogo do seu primeiro romance Pantagruel e apesar de se mostrar sarcasticamente convicto do sucesso editorial desta publicação, Rabelais inscreve claramente a sua narrativa numa tradição oral (a das lendas em torno dos gigantes fundadores, nomeadamente), recomendando aos leitores que a memorizem porque, "caso a aventura da imprensa venha a acabar" e os livros a perecerem, poderá assim continuar a circular de boca em boca para proveito de todos ${ }^{27}$. Nos séculos XVII e XVIII (e bem mais tarde ainda ${ }^{28}$ ), a leitura em voz alta não é apenas o apanágio dos meios mais populares. Leem-se e experimentam-se novas formas poéticas nos Salões aristocráticos e nas sociedades literárias; leem-se romances dialogados e textos clandestinos nas cidades e nas cortes. Se dúvidas houvesse sobre esta constante permeabilidade e complementaridade entre escrita e leitura, recorde-se que Furetière, no artigo "Ler" do seu Dictionnaire universel publicado em 1690, não consagra nenhuma entrada à escrita, definindo claramente, em contrapartida, a leitura

seio da corte portuguesa". Neste sentido, o Livro de Horas representa igualmente um espaço extremamente permeável de incessante comunicação entre a esfera privada e a esfera política, participando ainda de um movimento mais amplo - no qual D. Duarte teve um papel preponderante - de valorização do "discurso visual associado a um modelo social e comportamental de transição entre a Idade Média e a Moderna" (M. Metelo de Seixas e J. B. Galvão-Telles - "Elementos de uma cultura dinástica e visual: os sinais heráldicos e emblemáticos do rei D. Duarte". in BARREIRA, C. e METELO DE SEIXAS, M. (dir.) - D. Duarte e a sua época, op. cit., p. 279).

${ }^{26}$ Sobre esta questão, ver JANNERET, M. - "La littérature et la voix: attraits et mirages de l'oral au XVI siècle". in LESTRINGANT, F.; ZINK, M. (dir.) - Histoire..., pp. 212-233.

${ }^{27}$ Texto com tradução em francês moderno, prefácio e notas de Guy DERMESON. Paris: Seuil, 1997.

28 Depreende-se destas considerações que partilhamos inteiramente da conceção periodológica do historiador Jacques Le Goff para quem a Idade Média está longe de se esgotar com a viragem (ou pseudoviragem) para o Renascimento (sobre esta questão, veja-se ao seu último ensaio: Faut-il vraiment découper l'histoire en tranches. Paris: Seuil, 2014, pp. 137-186). As práticas, reais e simbólicas, e os discursos sobre a leitura surgem assim como um indicador privilegiado de uma "longa" Idade Média que se prolonga até ao século XVIII ou mesmo, pelo menos em certos aspectos, até aos dias de hoje. 
como o ato de "pronunciar em voz alta o conteúdo de um qualquer livro ou escrito que tenhamos diante dos olhos" e acabando por louvar a prática monástica que consiste em ler durante as refeições ${ }^{29}$ ! Assim, da mesma forma que será histórica e metodologicamente incorreto afirmar que a Idade Média foi apenas a época da leitura em voz alta, igualmente redutor será considerar que o mundo moderno e contemporâneo se caracteriza por um "imperialismo da escrita" em detrimento de uma "autonomie de la pratique lisante" (Michel de Certeau) ${ }^{30}$ ao assimilar tendencialmente o significante com a letra e a letra com a literatura. $\mathrm{Na}$ verdade, leitura silenciosa, leitura murmurada e leitura em voz alta sempre coexistiram, a crescente multiplicação de comunidades de leitores a que assistimos revelando claramente que a fruição estética, lúdica e cognitiva de um texto não dispensa nenhuma delas.

Esta consciência da interação simbiótica entre práticas da escrita e modos de leitura é essencial no âmbito de qualquer reflexão, metodologicamente rigorosa, sobre o estatuto, a função e o devir da leitura (seja ela silenciosa ou em voz alta) tanto do ponto de vista cognitivo e comunicacional como pedagógico. Neste sentido, dela não poderá ficar alheia a transferência da escrita para o espaço virtual e a multiplicação dos suportes tecnológicos nos quais se expande (smartphones, tablets, computadores portáteis e outros tantos dispositivos) que alteram profundamente as condições de leitura ao permitir, por exemplo, ampliar ou reduzir a mancha gráfica, possibilitando tanto uma apreensão global do texto/do sentido ou uma experiência mais analítica e meditativa em torno de qualquer pormenor. Que alteram igualmente as formas de oralidade (da oralidade simulada dos chats ou nas redes sociais à oralidade síncrona que vence a distância, passando pelas práticas de oralidade diferidas ou assíncronas). Que transformam finalmente a própria inscrição espácio-temporal do texto e a própria natureza e estatuto da escrita que agora se desdobra em espaços múltiplos (sucessivos ou simultâneos) que fazem do texto um autêntico e infinito palimpsesto ${ }^{31}$. A era digital vem decisivamente trazer novos desafios à leitura, alterando profundamente as suas

\footnotetext{
${ }^{29}$ Apud BIET, C. - "L'oral et l'écrit", art. cit., p. 434.

${ }^{30}$ L'Invention du quotidien, 1. Paris: Gallimard, 1990, p. 24.

${ }^{31}$ Esta complexa e fascinante questão do estatuto de literatura digital (ou projetada para ambientes virtuais) tem sido objeto de muitas investigações e publicações. Para uma introdução, vejam-se as reflexões de C. Vanderdorpe, nomeadamente sobre as relações entre códex e hipertexto: Du Papyrus à l'hypertexte, op. cit., pp. 235-252.
} 
condições materiais e sensoriais de produção e de receção, nomeadamente pelo modo como reconfigura as relações entre a letra e a voz numa cada vez mais complexa e intensa relação intersemiótica envolvendo uma diversidade crescente de discursos e de linguagens (imagem, vídeo, música, etc.) que tanto podem enriquecer e orientar a interpretação (no sentido hermenêutico como no de uma reapropriação através da voz) de um texto, como o podem transformar num autêntico labirinto donde ninguém regressa. Desafio também entre a fixação de um texto e a sua constante transformação pelo leitor virtual, entre a experiência privada e a partilha coletiva potenciada pela enorme facilidade como se alteram e enriquecem (com anotações à margem, por exemplo, à semelhança do códex da era escolástica) os ambientes nos quais o texto se inscreve, entre um aparente domínio do espaço/tempo próprio do imaginário livresco (indexação, marcadores hipertextuais) e uma subordinação ao império do tempo característica da transmissão oral, a página desenrolando-se no ecrã como outrora o volumem à volta seu eixo (rolo) central. A era digital cria assim uma nova aliança (não isenta de tensões), entre a voz e a escrita, entre a fruição solitária da literatura e a sua dimensão comunicativa e colaborativa, cujas implicações teóricas e práticas ainda estão longe de ter sido devidamente questionadas e exploradas.

\section{Leitura em voz alta e gramática da voz}

Esta tensão não é contudo nova, como sabemos, a história da civilização ocidental assentando, em grande parte, num irredutível e irresolúvel antagonismo, mais ou menos marcado ou violento consoante as épocas, entre uma idealização da escrita erguida à esfera mágica do sagrado (ou da Lei) que coloca a oralidade sob o signo da afabulação corruptora, e uma longa tradição que, de Platão a Saussure, passando por Aristóteles, Santo Agostinho e Hegel, assimila o logocentrismo a um fonocentristo em que escrita, significante do significante, não passa de uma cristalização redutora da voz da qual emana a totalidade do ser e a plenitude da palavra. Se a escrita implica sempre a Diferença (ou a Diferição, segundo Jacques Derrida), veiculando uma intransponível falha entre os signos e o mundo que sonha nomear/habitar; se, por outras palavras, a 
escrita é, por excelência, o lugar da eterna ausência ou do exílio ${ }^{32}$, a voz (phonè) mantém viva e pregnante a relação simbólica entre a linguagem e o logos primordial, os signos e a significação, entre o ser e a alma (Aristóteles dizia que "os sons emitidos pela voz são os símbolos dos estados de alma" ${ }^{, 33}$ ), numa copresença e imediatez absolutas que rebaixam a escrita ao estatuto de uma "mediação de mediação e queda na exterioridade do sentido" 34 . É provavelmente esta dimensão testemunhal e vertical da voz $^{35}$, na sua capacidade de transcender as contingências do tempo e da linguagem, substituindo-se ao próprio mundo que reanima incessantemente, que explica o seu estatuto singular não apenas em rituais de natureza sagrada mas também em certos contexto seculares (nos tribunais, por exemplo) onde só excecionalmente o testemunho escrito pode substituir a voz. Independentemente da sua intensidade ou elevação, a voz assume assim, na tradição filosófica ocidental, uma dimensão arquetípica (ou de acesso privilegiado ao mundo dos arquétipos, tanto na aceção platónica de imagem primordial como durandiana do termo enquanto matriz afetivo-representacional na origem dos símbolos e das imagens ${ }^{36}$ ), donde a sua associação a uma verdade imanente e a sua íntima relação com o desejo e o Conhecimento, com o Conhecimento enquanto desejo. Aceder, pela leitura ruminativa ou magistral, aos vários níveis de significação do Texto bíblico, do sentido literal ao sentido místico, constituía, para religiosos e escolásticos da Idade Média, um verdadeiro "itinerário da mente para Deus”, para retomar o título de um célebre tratado de São Boaventura. Através da leitura em voz baixa, meditativa e solitária, o monge opera uma autêntica operação gustativa e digestiva da palavra. A manducação torna-se análoga ao rito eucarístico de incorporação do Verbo feito carne.

\footnotetext{
${ }^{32}$ Ver DERRIDA: "L'écriture est le moment du désert comme moment de la Séparation" (L'Écriture et la Différence. Paris: Seuil, 1967, p. 104); "Écrire, c'est se retirer. Non pas dans sa tente pour écrire, mais dans son écriture même. S'échouer loin de son langage, l'émanciper ou le désemparer, le laisser cheminer seul et démuni”, Idem, p. 106).

${ }^{33}$ Da interpretação, 1, 16a 3, apud DERRIDA - De la Grammatologie. Paris: Les Éditions de Minuit, 1967, p. 21. Nas suas reflexões sobre a Estética (III, 1), Hegel inscreve-se assumidamente nesta tradição epistemológica na qual ecoa igualmente tanto Platão (nomeadamente no Teeteto e no Fedro) como Kant que considerava o diálogo vocal consigo mesmo como forma primeira do pensamento através da imaginação criadora (Antropologia de um ponto de vista pragmático de 1798): “[...] l'oreille, au contraire, sans se tourner pratiquement vers les objets, perçoit le resultat de ce tremblement intéreir du corps par lequel se manifeste et se révèle, non la figure matérielle, mais une première idéalité venant de l'âme".

${ }^{34}$ DERRIDA, J. - De la grammatologie, op. cit., p. 24.

${ }^{35}$ Ver o recente ensaio de B. CLEMENT - La Voix verticale. Paris: Belin, 2012.

${ }^{36}$ DURAND, G. - Les Structures anthropologiques de l'Imaginaire: introduction à l'archétypologie générale. Paris: Dunod, 1992, pp. 62-63.
} 
A “clara lectio", sublinha Orlando de Rudder" , "sensual, gustativa, cum palatum cordis (Jean de Fécamp), é a verdadeira leitura, a que ressoa a partir de um texto mil vezes lido, decorado, novamente revisitado pela memória, salmodiado, meditado, as palavras repetindo-se à exaustão até perderem o seu sentido manifesto... e verem então brotar, através da meditação, da ruminação, novos sentidos, alegóricos, metafóricos, anagógicos, que emergem da livre associação das palavras e das ideias... Existe uma música que está na letra mas que não pertence à letra, como existe, para lá da carne, o inefável...”. Daí também a importância estruturante, numa altura em que não existe ainda uma ortografia estabilizada e normativa, dos jogos sonoros a partir dos significantes literais (retórica da annominatio, paronomásias, homofonias, etc.) numa constante e subliminar (des)construção do sentido que acompanha a ficção medieval.

Mas é também porque nos religa constantemente a uma memória ancestral do mundo e da Criação que a voz é revelação, oráculo, inspiração, profecia. Quando, na sua Summa Theologicae (IIIa, quaestio 42, art. 4) ${ }^{38}$ São Tomás de Aquino se questionava por que razão Cristo nunca escrevera quando a escrita tem precisamente por vocação "confiar uma doutrina à memória", responde que, devido à sua dignidade e superioridade, os ensinamentos de Cristo (como o de Pitágoras ou de Sócrates, aliás) nunca poderiam caber nos limites aprisionadores e semanticamente redutores da palavra escrita ${ }^{39}$. Na literatura profana, os exemplos são igualmente abundantes e eloquentes. O romance anónimo em prosa de Perlesvaus (ou Le Haut Livre du Graal - início do século XIII), confere assim a José de Arimateia o estatuto de um auctor privilegiado (testemunho da Revelação) que recebe e transcreve as palavras ditadas pela voz do Anjo ${ }^{40}$. No final do Roman de Merlin de Robert de Boron (século XIII), Merlim, o famoso mago ao serviço

\footnotetext{
${ }^{37}$ Art. cit., p. 102 (sou eu quem traduzo).

${ }^{38}$ Ed. Bilingue (Latim/Espanhol) de S. RAMIREZ, t. II. Madrid: La Editorial Católica, col. BAC, 1959.

${ }^{39}$ São Tomás conclui então o seu raciocínio opondo, no seguimento das palavras de São Paulo aos Coríntios, a escrita a tinta - enquanto manifestação visível e sensível da Lei divina - à voz de Cristo, enquanto manifestação do espírito vivo: "Porque já é sabido que vós sóis uma carta de Cristo escrita por nós, e escrita, não com tinta, mas com o Espírito de Deus vivo, não em tábuas de pedra, mas em tábuas de carne, nos vossos corações" (Coríntios, II, 3, 3).

40 "Voici l'histoire de la très sainte coupe (vessel) qu'on nomme le Graal, dans laquelle fut recueilli le précieux sang du Sauveur le jour où Il fut crucifié pour racheter les hommes. C'est Joséphé qui en a écrit le récit, sous la dicté d'un ange, afin que par son témoignage soit connue la vérité sur les chevaliers et les saints hommes qui acceptèrent de souffrir peines et tourments pour glorifier la religion que Jésus-Christ a voulu instituer par Sa mort sur la Croix (Branche I, Prólogo, 123: texto traduzido e apresentado por C. MARCHELLO-NIZIA. in REGNIER-BOHLER, D. - La Légende arthurienne. Le Graal et la Table Ronde. Paris: Robert Laffont, 1989).
} 
do rei Artur, substitui-se à voz do Anjo-mediador em Perlesvaus e usurpa o lugar do Criador no seu papel de auctor demiúrgico ao ditar os seus conhecimentos e revelações a Blaise. Este último assume então claramente a função do poeta medieval enquanto copista (ou escriba) de uma palavra anterior destinada a ser guardada/consagrada no espaço material e inviolável do Livro (“ainsis sera tes livres celez”, 16, 102-103"1) cuja superioridade moral, autenticidade e autoridade não deixa contudo de ter origem na transcendência exemplar da voz:

“(...) et je te dirai tel chose que nus hom, fors Dieu et moi, ne te porroit dire. Si en fai un livre et maintes genz qui se livre orront en serront meillor et se garderont plusx de pechier, si feras aumones et metras t'ovre en bien [...]. Or quier encre et parchemin adés, car je te dirai maintes choses que tu ne cuideroies que nus hom poïst dire" $(16,37-41 ; 59-61)$.

Pneumática e seminal, a voz surge simultaneamente como princípio diferenciador, ordenador (a voz divina que cria o mundo, nomeando os elementos, começa sempre por introduzir uma separação ordenadora a partir do caos - ou plasma primordial indiferenciado) e reunificador, totalizante. Não deixa de ser interessante Isidoro de Sevilha (séc. VII) fazer da vox articulata o impulso fundador da gramática enquanto scientia recte loquendi (Etimologias, I, 5) ${ }^{42}$, que antecede inclusive, na sua descrição, os aspetos morfológicos, prosódicos, sintáticos e retóricos que participam na construção dos enunciados gramaticais. A articulação desempenha, de resto, um papel fulcral, tanto do ponto de vista de uma pedagogia da leitura como no âmbito de uma epistemologia centrada na phonè: a articulação, nomeadamente no contexto de uma leitura em voz alta, é aquilo que distingue o indiferenciado sonoro (ruídos, choros, risos ou gritos, sejam eles humanos ou animais) da palavra fecunda e fecundante. Num contexto de pregação, onde a disseminação vocal da palavra divina ganha particular importância, vários exempla medievais condenam os religiosos que mastigam e devoram as sílabas quando recitam o ofício divino; sílabas de que o diabo se apropria guardando-as num saco até ao Juízo Final ${ }^{43}$. Na sua Historia occidentalis (primeira metade do século XIII),

${ }^{41}$ ROBERT DE BORON, Merlin, ed. A. MICHA. Genebra: Droz, 1979.

${ }^{42}$ Ed. Bilingue (Latim/Espanhol) de J. OROZ RETA e M. A. MARCOS CASQUERO. T. 1. Madrid: BAC, 1982.

${ }^{43}$ É o que explica, num dos seus sermões, Cesário de Heisterbach (citado por J. Th. Walter nas notas à sua edição da Tabula exemplorum, p. 134): "Modo in ecclesia quidam raro orant, immo nec horas debito

Medievalista online № 19| Janeiro - Junho 2016 (C) IEM - Instituto de Estudos Medievais 19 
o pregador Jacques de Vitry (capítulo XXXIV, pp. 206-212) critica violentamente, no âmbito das suas considerações sobre a oração, este mau hábito de muitos eclesiásticos, retomando a imagem do diabo que recolhe num saco as sílabas engolidas e roubadas a Deus $^{44}$. Da atmosfera religiosa do século XIII para o contexto laico e pedagógico do Renascimento ou do Iluminismo, o primado da articulação desloca-se, mantendo-se contudo inalterado na sua essência. No seu tratado Défense et illustration de la langue française (II, X) de $1549^{45}$, Joaquim Du Bellay sublinha, também ele, a importância de pronunciar os sons de forma perfeitamente articulada, não-confusa, viril e não efeminada, adequando a pronunciação aos gestos e sentimentos expressos nos versos, os ouvidos repudiando, por natureza, as coisas rudes e ásperas. Mesma insistência no romance educativo de Jean-Jacques Roussseau, L'Émile ou de l'Éducation (1762), ao insistir numa pedagogia da leitura assente na dicção clara e bem articulada, única capaz de transmitir tanto o sentido gramatical como a prosódia de um texto e permitir assim o acesso ao sentido (Livro II, p. $109^{46}$ ). Note-se que não é certamente por acaso que muitas patologias físicas registadas na literatura médica e ficcional da Idade Média (e muito para lá dessa época), do andar assimétrico à surdez, estão intimamente ligadas a uma disfunção verbal. Como também não será por acaso que um dos traços míticos de muitos profetas e eleitos de Deus reside paradoxalmente na gaguez ${ }^{47}$, signo da imensidão da palavra divina que não cabe nos limites articulatórios da palavra humana levando-a a desarticular-se.

modo dicunt vel eas dimittentes vel quid dicunt non attendes vel dictones vel versus furantes vel sillabas syncopantes vel nugas facientes et Deo illudentes."

44 “Qu'il évite [o sacerdote] de prier avec une telle négligence qu'il en vienne à se répéter dans sa prière. Il n'aura pas besoin de répéter s'il a pris soin de proférer les mots sans estropier la diction. Qu'on ne s'avise pas de dérober au seigneur des syllabes, des expressions, voire des prières entières par une hâte excessive, à la manière de certains prêtres déraisonnables qui, honorant le seigneur par leur lèvres, tournent sans respect leur cœurs vers des choses vaines et inutiles [...]. Voici ce que nous avons entendu rapporter par certains. Un jour notre ennemi, l'accusateur des frères et le calomniateur du genre humain, apparut, comme quelqu'un de lourdement chargé, à un pieux religieux dans les chœurs des moines qui chantaient. Au frère qui l'interrogeait sur ce qu'il portait, qui semblait un sac plein posé sur ses épaules, Satan répondit: 'Ce sont les syllabes escamotées dans la psalmodie par ces moines, ainsi que les mots et les vers des psaumes qu'ils ont, tels des voleurs, soustraits cette nuit au service de Dieu et dont ils rendront compte"' (Tradução de G. DUCHET-SUCHAUX, com introdução e notas de J. Longère. Paris: les Éditions du Cerf, 1997, p. 208).

${ }^{45}$ Ed. S. DE SACY. Paris: NRF-Gallimard, 1975.

${ }^{46}$ Paris: Garnier-Flammarion, 1961.

${ }^{47}$ Limitando-nos à esfera bíblica, vejam-se os exemplos de Moisés (Êxodo, 3), Jeremias (Jr. 20, 9) ou Amós (Am. 3, 8).

Medievalísta online № 19| Janeiro - Junho 2016 (c) IEM - Instituto de Estudos Medievais 20 


\section{Voltar a olhar para o céu: a voz ou a sedução da literatura}

Se a voz, manifestação de uma plenitude simbólica e ontológica que a leitura em voz alta faz naturalmente ressoar de forma privilegiada, reúne os fios do tempo religando a memória das origens à intuição do devir, é também ela que garante a coesão do presente. A sua eficácia pressupõe, no entanto, a participação plena de um sujeito dual, a palavra lida ou recitada tornando-se fértil apenas se tiver um ouvinte que a acolhe, interioriza e fecunda. É a esta metáfora vegetal, inspirada na Parábola do Semeador, que Chrétien de Troyes recorre no prólogo do seu último romance, Perceval (Le Conte du Graal), para enaltecer as virtudes do mecenas, comendatário e destinatário privilegiado da obra (Filipe de Flandres). Mas é também sobre esta dimensão iniciática do ato de ouvir que insiste Calogrenant, herói falhado do terceiro romance do mesmo autor (Yvain ou Le Chevalier au Lion), quando decide, depois de sete longos anos de um silêncio matricial, contar perante a corte, a sua desventura:

\footnotetext{
“(...) or entendés!

Cuer et oroeilles me rendés, car parole oïe est perdue s'ele n'est de cuer entendue. Or y a tix que che qu'il oent n'entendent pas, et si le loent; et chil n'en ont fors que l'oïe, puis que li cuers n'i entent mie; as oreilles vient le parole, aussi comme li vens qui vole, mais n'i arreste ne demore, ains s'en part en mout petit d'ore, se li cuers n'est si estilliés c'a prendre soit appareilliés; que chil le puet en son venir prendre et enclorre et retenir. Les oreilles sont voie et dois ou par ent y entre la vois; et li cuers prent dedens le ventre le vois qui par l'oreille y entre. Et qui or me vaurra entendre, cuer et oreilles me doit rendre, car ne veul pas servir de songe,
} 
A voz ou a plenitude do texto. Performance oral, práticas de leitura e identidade literaria

no Ocidente medieval $\bullet$ Carlos F. Clamote Carreto

ne de fable, ne de menchonge" (v. 149-172).

Nesta admirável poética da receção, construída em torno das reiteradas oposições entre o ouvir e o escutar, o ouvido e o coração, a potencial dispersão da palavra através da voz e a sua reunificação interior, vemos desenhar-se uma verdadeira iniciação à leitura (ou, mais precisamente, à leitura como iniciação) em que o ouvido é "via e caminho" para o Centro através dos quais a voz se transforma em Conhecimento. A trajetória interior que conduz a "anclorre et retenir" (v. 164) no coração as palavras veiculadas pela voz (ou seja, literalmente, aprender de cor) traduz poeticamente toda esta epistemologia fonocêntrica que temos vindo a esboçar e na qual assenta a própria integridade da narrativa que se distancia assim da impostura da fábula em que os meandros ruidosos da transmissão oral se tornam cada vez mais sinónimo de corrupção ou de fragmentação da palavra poética ${ }^{48}$. Será por mero acaso se, numa das cenas que encerra este poema, numa posição estrutural diametralmente oposta ao conto de Calogrenant que o inaugura, assistimos à discreta e breve descrição de uma cena intimista em que uma donzela lê, em voz alta, para seus pais, um romance no ambiente idílico de um vergel $?^{49}$

Estas encenações ficcionais da oralidade, como se a narrativa espelhasse as suas próprias condições de transmissão, não é naturalmente de estranhar numa obra medieval. Com efeito, nunca será de mais relembrar que, quando as literaturas modernas (ou seja, as literaturas em língua vernácula, a língua ficcional do desejo por

\footnotetext{
${ }^{48}$ Vemos assim desenhar-se uma subtil nuança entre transmissão oral e transmissão vocal da obra a partir de uma fonte íntegra, Chrétien de Troyes sendo um dos primeiros poetas a procurar exorcizar claramente, desde o seu primeiro romance, o espectro da tradição oral representada pelos jograis profissionais que deformam o conto: "D'Erec, le fil Lac, est li contes,/ Que devant rois et devant contes/ Depecier et corrompre suelent/ Cil qui de conter vivre vuelent" (v. 19-22 da ed. J.-M. FRITZ. in Chrétien de Troyes. Romans, op. cit., p. 61. Neste sentido, muitos serão os poetas que, na esteira de Calogrenant, irão insistir sobre a dimensão iniciática nas narrativas reveladas pela voz ou a escrita. Veja-se o exemplo do prólogo de La Manekine de Philippe de Beaumanoir: "Car biaus contes si est perdus,/ Quant il n'est de cuer entendus,/ Meïsmement a chiaus qui l'oënt (v. 25-27 da ed. H. SUCHIER. in Euvres complètes de Philippe de Beaumanoir. Vol. I. Paris: Société des Anciens Textes Français, 1984-85).

${ }^{49}$ Ver passagem citada em epígrafe. Sobre este motivo, ver CERQUIGLINI-TOULET, J. - "La scène de la lecture dans l'œuvre littéraire au Moyen Âge". in BOHLER, D. (dir.) - Le Goût du lecteur à la fin du Moyen Âge. Paris: Léopard d'Or, 11, 2006, p. 13-26. No final da Idade Média, continuam a multiplicarse, nas obras literárias, as referências explícitas a uma leitura (pública ou mais intimista) para outrem: Guillaume de Machaut (Le Livre du voir-dit [1364], v. 721-726 da ed. P. IMBS. Paris: Librairie Générale Française, col. "Lettres Gothiques", 1999); Christine de Pisan (Livre de la mutacion de Fortune [14001403], Le Dit de la Rose [1401], Le Débat des deux amants, Livre de l'Advision de Christine, Livre des trois vertus), etc.
}

Medievalísta online № 19| Janeiro - Junho 2016 () IEM - Instituto de Estudos Medievais 22 
excelência em contraste com o latim) emergem na Europa ocidental nos séculos XI-XII a partir dos epicentros occitano e anglo-normando, a sua existência é consubstancial à performance oral (as cópias manuscritas são todas mais tardias). Esta performance depende intimamente das condições (espaciais, temporais, materiais) em que se realiza, condicionando, por sua vez, não apenas o modo de receção da obra como a sua própria estrutura formal e semântica. É a voz, com toda a espessura da tradição e do mito que por ela perpassa e que com ela renasce, mas também com toda a sua fragilidade e volatilidade, como relembrava Calogrenant, que molda e atualiza incessantemente a narrativa, ecoando ainda na instabilidade intrínseca da obra medieval, variável por natureza e vocação ${ }^{50}$, que pouco se coaduna com a nossa ideia de texto enquanto forma perfeitamente circunscrita, tecida e acabada ${ }^{51}$. Se do registo romanesco, mais centrado na problemática de uma individualidade emergente, passarmos para a canção de gesta, este primado da voz torna-se ainda mais eloquente. Raros são os poemas épicos dos séculos XII e XIII que não se definem explicitamente, desde os versos inaugurais, como uma comunicação oral subordinada à autoridade da voz que, graças à sua capacidade única de mobilizar/atualizar o passado garante a autenticidade da narrativa. Associada a uma estética da repetição e a uma poética da memória (organização da matéria por estrofes [laisses] temáticas ou diegéticas unidas por rimas sonantes; sintaxe e estilo iterativo e formulístico, etc. $)^{52}$, a centralidade da voz na canção de gesta transforma este género narrativo em verdadeira celebração litúrgica dos feitos heroicos que visa fortalecer e exaltar a coesão e a estabilidade da comunidade textual na qual ressoa ${ }^{53}$, nela assumindo um estatuto ontológico idêntico ao do próprio testemunho visual:

\footnotetext{
${ }^{50}$ Sobre esta questão, ver os trabalhos pioneiros de Paul Zumthor.

${ }^{51}$ Ver CERQUIGLINI, B. - Éloge de la variante. Histoire critique de la philologie. Paris: Seuil, 1989.

${ }^{52}$ Ver, por exemplo, os trabalhos de BOUTET, D. - La Chanson de geste: forme et signification d'une écriture épique du Moyen Âge. Paris: PUF, 1993; "L'oral et l'écrit dans la France médiévale". in LESTRINGANT, F.; ZINK, M. - Histoire de la France Littéraire, op. cit., pp. 193-212.

53 "La voix, en effet, unit; seule l'écriture distingue efficacement entre les termes de ce dont elle permet l'analyse. Dans la chaleur des présences simultanées, en performance, la voix poétique n'a d'autre fonction ni d'autre pouvoir que d'exalter cette communauté, dans le consentement ou dans la résistance [...]. ["Fiction" et "réalité historique" procèdent, tous ensemble, d'une même instance : la tradition mémorielle transmise, enrichie et incarnée par la voix. D'où le prestige du déjà-dit, de l'ancien. Tout temps est épique : mesuré aux seuls mouvements collectifs des sensibilités et des corps, dans l'harmonie de la performance. Tel fut, des siècles durant, le trait fondamental d'une culture [...]" (ZUMTHOR, P. La Lettre et la voix, op. cit., p. 159).
} 
A voz ou a plenitude do texto. Performance oral, práticas de leitura e identidade literaria

no Ocidente medieval $\bullet$ Carlos F. Clamote Carreto

Segnor, soiés en pais, laisiés la noise ester,

Se vos volés cançon glorieuse escouter.

Ja de nule mellor ne vos dira jougler (La Chanson d'Antioche [séc. XII], v. 1-3 ${ }^{54}$ ).

Oiés, signor - que Dex vos soit garans,

Li glorious qui sour tous est poisans ! -

Boine cançon oiés que je vous cant

De voire estore, li vier en sont plaisant (La Chevalerie Vivien, II, v. 27-30) ${ }^{55}$.

Ceste cançons si est de verité,

N'est de mençogne ne n'est de fauseté,

Ains est d'estore de grant antiquité,

De saint Guillaume [...] (Idem, III, v. 53-56).

Oëz, seignor, que Dex vos beneïe,

Li glorïeus, li filz sainte Marie,

Bone chançon que ge vos vorrai dire!

Ceste n'est mie d'orgueill ne de folie,

$\mathrm{Ne}$ de mençonge estrete ne emprise,

Mes de preudomes qui Espaigne conquistrent.

Icil le sevent qui en vont a Saint Gile,

Qui les ensaignes en ont veü a Bride:

L'escu Guillelme et la targe florie,

Et le Bertran, son neveu, le nobile.

Ge ne cuit mie que ja clers m'en desdie

Ne escripture qu'en ait trové en livre (La Prise d'Orange, v. 1-12). ${ }^{56}$

${ }^{54}$ Ed. S. DUPARC-QUIOC. Paris: Librairie Orientaliste Paul Geuthner, 1977.

${ }^{55}$ Versão do $m s$ E I. Ed. D. MCMILLAN. Aix-en-Provence: Université de Provence [Sénéfiance, 39-40], 1997, pp. 470-482.

56 Ed. Cl. RÉGNIER. Paris: Klincksieck, 1986.0 caso de Aiol (séculos XII-XIII) é igualmente interessante, na medida em que enraíza a narrativa atualizada pela voz num tempo mítico que remonta, de forma ininterrupta, aos primórdios da Criação (Adão e Eva) e cuja integridade e memória são ameaçados pelos jograis, emblema da fábula corruptora que se opõe à verdade da história épica: "Signor, or escoutés, que Dieus vos soit amis/ Li rois de sainte gloire qui en la crois fu mis,/ Qui le ciel et le tere et le mont establi/ Et Adan et Evain forma et benei!/ Canchon de fiere estoire plairoit vos a oir?/ Laissiés le noise ester, si vos traiés vers mi./ Cil novel jougleor en sont mal escarni:/ Por les fables qu'il dient ont tout mis en obli;/ La plus veraie estoire ont laisiet et guerpi:/ Je vos en dirai une qui bien fait a cierir./ A tesmoig en trairoie maint franc home gentil/ Et maint duc et maint conte et maint riche marchis./ N'est pas a droit joglere qui ne set ices dis,/ Ne doit devant haut home ne aler ne venir;/ Teus en quide savoir qui en set molt petit,/ Mais je vos en dirai qui de lonc l'ai apris" (v. 1-16 da ed. J. NORMAND e G. RAYNAUD. Paris: Didot, Société des Anciens Textes Français, 7, 1877).

Medievalísta online No 19| Janeiro - Junho 2016 (C) IEM - Instituto de Estudos Medievais 24

www2.fcsh.unl.pt/iem/medievalista 
O prestígio vibrante da voz poética - que silencia os ruídos tumultuosos, difusos e vazios das palavras comuns -, a sua natureza unificadora e totalizadora (não esqueçamos que os jograis são intérpretes itinerantes por excelência), consubstancial à realidade que enuncia, logo, indesmentível, sofre contudo, entre o início do século XII e meados do século $\mathrm{XV}$, um certo desgaste devido à generalização da escrita (e não da leitura) no seio da cultura "mista" ${ }^{57}$ que define o Ocidente medieval. Contudo, ao olharmos com mais atenção para os textos, verificamos que, no seio desta tensão dialética, não é tanto a voz que está posta em xeque, mas sim a legitimidade e a autoridade de uma transmissão puramente oral da narrativa. À única referência autolegitimante da voz, começa então a emergir dos prólogos a reiterada menção à presença (mais fictícia do que real) de um livro do qual emana a narrativa descoberta (retórica da inventio) e transmitida (poética da translatio) pelo poeta ou o jogral. Trata-se de uma inflexão duplamente reveladora. Por um lado, porque desloca claramente a performance oral (misto de recitação e improviso) para a esfera da leitura em voz alta a partir de um suporte idealmente fixo e estável. Por outro lado, porque transfere a fonte da autoridade da voz para a escrita ${ }^{58}$. Com efeito, subordinado às noções de História (por oposição ao espectro da fábula vã ${ }^{59}$, de completude, de sacralidade de um espaço (o mosteiro) e de uma língua (o latim do qual a obra será trasladada para romance), de corporeidade significante de uma palavra tangível com a qual a voz e a verdade da ficção podem agora ser constantemente confrontadas ou cotejadas, o imaginário do livro - que virá, de resto, a ser consubstancial à emergência da própria escrita ficcional em prosa no século XIII $^{60}$-, acaba por exorcizar ou secundarizar a voz. Os exemplos são abundantes. Vejase o exemplo do Moniage Guillaume (séc. XII):

\footnotetext{
${ }^{57}$ ZUMTHOR, P. - La Lettre et la voix, op. cit., pp. 18-19.
}

${ }^{58}$ Sobre o papel da leitura na composição da obra medieval e as suas implicações na transformação da identidade autoral, vejam-se as considerações de VAN HEMELRYCK, T. - "Du livre lu au livre écrit. La lecture et la construction de l'identité auctoriale à la fin du Moyen Âge". in HERMAND, X., RENARD, E. e VAN HOOREBEECK, C. (dir.) - Lecteurs, lectures et groupes sociaux au Moyen Âge. Turnhout: Brepols, 2010, pp. 185-194.

${ }^{59}$ Sobre as noções centrais de Fábula, Historia e Argumento, herdadas da retórica clássica, vejam-se as definições de Isidoro de Sevilha (Etimologias, I 40-44).

${ }^{60}$ Com efeito, sob a máscara paradoxal de uma sintaxe que sonha colmatar os hiatos e não-ditos da ficção em verso, a narrativa em prosa do século XIII virá consumar definitivamente esta translatio do Livro para um espaço puramente autorreferencial da ficção. Embora a escrita em prosa não substitua totalmente a estética do verso nem pretenda ter o monopólio da verdade, é inegável que nesta nova forma de representação (narrativização) do mundo, a rima se associa cada vez mais à noção de falsidade ou mentira, como se a ideologia vigente tendesse a ficar progressivamente surda à música do universo que 
A voz ou a plenitude do texto. Performance oral, práticas de leitura e identidade literaria

no Ocidente medieval $\bullet$ Carlos F. Clamote Carreto

Bone chançon pleroit vous a oïr ? [...]

De fiere geste bien sont les vers assis;

N'est pas juglerres qui ne set de cestui;

L'estoire en est au mostier Saint Denis,

Molt a lonc tens qu'ele est mise en oubli;

Molt fu preudom cil qui rimer la fist (v. 3-7 $)^{61}$.

A história de Berte aus grans piés de Adenet le Roi (séc. XIII), que se propõe revelar as origens genealógicas do próprio imperador Carlos Magno, é particularmente interessante, não somente pela minuciosa encenação narrativa e simbólica que preside à providencial descoberta o livro-fonte e à sua translatio para romance cuja exemplaridade assume uma dimensão quase iniciática, mas também pelo facto de estabelecer uma relação tão intrínseca entre escrita e performance oral que sugere claramente uma apropriação/atualização do texto através de uma situação de leitura em voz alta:

A l'issue d'Avrill, un tans douç et joli,

Que herbeletes pongent et pre sont raverdi

Et arbrissel desirent qu'il fussent parflori,

Tout droit en cel termine que je ici vous di,

A Paris la cité estoie un venredi;

Pour ce qu'il ert devenres, en mon cuer m'assenti

emana do verso. Esta não é, contudo, uma ideia nova. Já nas Etimologias Isidoro de Sevilha faz derivar prosa da expressão $\operatorname{pro}(r)$ sum que significa "em linha reta", a prosa encarnando assim o ideal de retidão gramatical (I, 38, "De prosa"). Séculos mais tarde, Brunetto Latini (Li Livres dou tresor, III, 10, 1-5) definirá a prosa como um discurso mais natural, mais fluente, e, por conseguinte, mais próximo da linguagem comum e da oralidade (daí talvez o sucesso da prosa se dever também, possivelmente, à progressiva laicização do saber e à emergência de um público mais heterogéneo e vasto - a pequena nobreza, a burguesia urbana e mercantil, por exemplo - com uma sensibilidade estética diferente). Nesta perspetiva, o verso só podia, de facto, estar associado ao registo artificial, vão, subversivo ou instável da fábula ou da transmissão puramente oral. Sobre esta problemática, ver GALDERISI, Cl. - "Vers et prose au Moyen Âge". in LESTRINGANT, F. ; ZINK, M. (dir.), Histoire..., pp. 745-766 ; SEGUY, M. - Les Romans du Graal ou le signe imaginé. Paris: Champion, 2001.

${ }^{61}$ Ed. N. ANDRIEUX-REIX. Paris: Champion, 2003. Encontramos idêntica retórica da legitimação da narrativa do domínio romanesco. Veja-se o famoso prólogo de Chrétien de Troyes ao seu segundo romance, Cligès: "Ici comence li romanz de Cligés (...)./ Ceste estoire trovons escrite,/ Que conter vos vuel et retraire,/ En .I. des livres de l'aumaire/ Mon seignor saint Pere a Beauvez;/ De la fu cist contes estrez/ Dont cest romanz fist Crestiens./ Li livres est molt anciens/ Qui tesmoigne l'estoire a voire:/ Por ce fet ele meulz a croirre./ Par les livres que nos avons/ Les faiz des anciens savons/Et dou siecle qui fu jadis./ Ce nos ont nostre livre apris/ Que Grece ot de chevalerie/ Le premier los et de clergie./ Puis vint chevalerie a Rome/ Et de la clergie la somme,/ Qui or est en France venue./ Dex doint qu'ele i soit retenue (...)" (v. 1 e 18-36 : Ed. Ch. MELA e O. COLLET. in Chrétien de Troyes. Romans, op. cit., p. 291).

Medievalísta online No 19| Janeiro - Junho 2016 (c) IEM - Instituto de Estudos Medievais 26 
A voz ou a plenitude do texto. Performance oral, práticas de leitura e identidade literaria

no Ocidente medieval $\bullet$ Carlos F. Clamote Carreto

K'a Saint Denis iroie por priier Dieu merci.

A un moine courtois, c'on nonmoit Savari,

M'acointai telement, Damedieu en graci,

Que le livre as estoire me moustra et g'i vi

L'estoire de Bertain et de Pepin aussi

Conment n'en quel maniere le lion assailli;

Aprentiç jougleour et escrivain mari,

Qui l'on de lieus en lieus ça et la conqueilli,

Ont l'estoire fausse, onques mais ne vi si.

Illueques demorai de lors jusqu'au mardi

Tant que la vraie estoire enportai avoec mi,

Si conme Berte fu en la forest par li,

Ou mainte grosse paine endura et soufri,

L'estoire iert si rimee, par foi le vous plevi,

Que li mesentendant en seront abaudi

Et li bien entendant en seront esjoy.

$[\ldots]$

Seignor, or escoutez, pour Dieu ne vous anuit,

Si orrez vraie estoire dont li ver sont bien duit.

Molt volentiers la doivent oïr toute et tuit,

Car il en est molt poi, si com je crois et cuit,

Qui de vraie matere a cesti ci s'apuit ;

A Saint Denis en France, la ens ai mon acuit,

Ou je trouvai l'estoire dedenz un livre estuit (v. 1-22;898-904) ${ }^{62}$.

A ficção do livro não pretende apagar a voz nem erradicá-la, longe disso, da vida e da trajetória da narrativa. Inaugura, no entanto, uma viragem cultural cujas consequências ainda hoje influenciam a nossa forma de pensar, de sentir e de nos relacionarmos com os livros e com a leitura. Com efeito, secundarizar a voz sujeitando-a à autoridade da escrita, sugere claramente que a voz é (como sempre será) o "Outro da escrita"63. Um Outro incómodo e perturbador porque radicalmente livre, difuso, incontrolável e sedutor como o canto das sereias. Não admira, neste sentido, que numa época em que a escrita procura afirmar a sua hegemonia, a sua estratégia de legitimação passe por exorcizar ou neutralizar o poder desestruturante, encantatório e disseminador da voz, subordinando-a,

${ }^{62}$ Ed. A. Henry. Genebra: Droz, 1982.

${ }^{63}$ ZUMTHOR, P. - La Lettre et la voix, op. cit., p. 135.

Medievalista online № 19| Janeiro - Junho 2016 @ IEM - Instituto de Estudos Medievais 27

www2.fcsh.unl.pt/iem/medievalista 
no ato de leitura, à instância da escrita que, através da figura do livro, sonha cada vez mais em confundir a literatura com a finitude, estabilidade e completude ideais de um texto $^{64}$.

É evidente que a natureza da voz e o estatuto e manifestações da leitura na civilização contemporânea, marcadamente visual e semiológica, difere profundamente da voz (hoje totalmente inaudível e inalcançável na sua corporeidade histórica) que ecoa nos e dos textos de uma Idade Média eminentemente simbólica. Contudo, ontem como hoje, a atenção à voz continua a ser uma forma privilegiada de pensarmos a relação dialética entre competências ligadas à escrita e competências relacionadas com a oralidade, entre apreensão silenciosa do texto e a sua transmissão vocal, na condição de deslocarmos definitivamente o foco metodológico de uma falaciosa perspetiva cognitivista ou evolucionista para uma perspetiva pragmática em que ler em voz alta consiste em assumir plenamente que um texto poético é, antes de mais, um ato intencional de comunicação (independentemente da intenção do seu autor) ${ }^{65}$ implicando uma visão partilhada do mundo. Se a leitura solitária favorece a exploração simultaneamente analítica e global do texto, a sua interiorização, seja para que fim for, só a leitura articulada em voz alta pode transformar plenamente o texto em pulsão emotiva que faz vibrar tanto o corpo que sustenta a voz como o que a recebe ${ }^{66}$. É por esta razão que há

\footnotetext{
${ }^{64}$ Como inicialmente relembrávamos, recorde-se que "Il n'est qu'un texte au Moyen Âge. À partir du XI siècle (...), textus désigne de plus en plus exclusivement le codex Evangiliorum: tiste, en français, attesté vers 1120, puis refait en texte (c'est un mot savant), signifie "livre d'évangile". Ce texte, c'est la Bible, parole de Dieu, immuable, que l'on peut certes gloser mais non pas récrire. Énoncé stable et fini, structure close: textus (participe passé de textere) est ce qui a été tissé, tressé, entrelacé, construit; c'est une trame. Forme accomplie du verbe tisser, textus possède une connotation de fixité, de complétude structurelle à laquelle la pensée textuaire donnera une pleine vigueur sémantique, c'est à dire dénotative. L'écriture médiévale en revanche est une reprise; elle raboute, tisse à nouveau et perpétuellement des œuvres, œuvre sans cesse (...)" (CERQUIGLINI, B. - Éloge de la variante, op. cit., p. 59). No final da Divina Comédia, também Dante opõe as imagens de um mundo terreno fragmentado e de uma palavra poética igualmente imperfeita e balbuciante à figura transcendental do Livro do Universo encadernado pelo Amor divino e abrigando a totalidade do Sentido: "Nel suo profondo vidi che s'interna,/ legato con amore in un volume,/ ciò che per l'universo si/ quaderna:/ sustanze e accidenti e lor costume/ quasi conflati insieme, per tal modo/ che ciò ch'i dico è un semplice lume" (Paradiso, XXXIII, v. 85-90 da ed. bilingue de V. GRAÇA MOURA. Lisboa: Bertrand, 1995).

${ }^{65}$ Sobre esta questão, ver os acutilantes argumentos de SCHAEFFER, J.- M. - Petite écologie des études littéraires. Pourquoi et comment étudier la littérature? Vincennes: Éditions Thierry Marchaisse, 2011, pp. 83-103.

${ }^{66}$ Esta distinção funcional - ou pragmática - entre a leitura para si como forma de apreender o sentido e a leitura comunicativa para outrem, já se encontrava, de resto, claramente formulada por Hugo se São Vítor no seu Didascalicon (III, 7): "Lectio est, cum ex his quae scripta sunt, regulis et praeceptis informamur.
}

Medievalista online No 19| Janeiro - Junho 2016 (C) IEM - Instituto de Estudos Medievais 28 
pouco afirmávamos que a voz é sedução. Ora, como o segredo (o étimo é, de resto, o mesmo), a sedução é aquilo que separa. Que separa de quê? Que provavelmente nos separa de nós próprios, a voz sendo esse fluido que, mais do que a palavra escrita, nos impele a abandonar o nosso confortável lugar de leitor/espetador para imergirmos totalmente, através na mimese ficcional, no texto através do qual reconfiguramos incessantemente a nossa visão do mundo bem como a nossa própria identidade narrativa ${ }^{67}$. Não é por acaso que os autores clássicos consideravam o movere como um dos princípios essenciais da retórica a par das suas funções cognitiva (docere) e lúdica (delectare). E também não será por mero acaso se, ao, longo dos séculos, a prosopopeia surge como uma das figuras por ventura mais produtivas no processo de criação poética enquanto vestígio de um pensamento mítico onde o mundo (animal, mineral ou vegetal) só se pode pensar e dar a conhecer através da voz ${ }^{68}$. Sempre que lemos em voz alta, é um pouco deste universo ancestral que desenterramos. $\mathrm{O}$ que nos conduz a um novo paradoxo: a voz nunca é uma apropriação redutora do sentido, uma simples interpretação que esvazia parcialmente a dimensão metafórica do texto poético. Pelo contrário, através das modulações da voz, das suas hesitações, contra-dicções, quebras, silêncios e hiatos, a voz introduz-nos no universo do inter-dito, dos interstícios do pensamento e da linguagem, ou seja, da equivocidade polifónica e dialógica em constante resistência às tentativas hegemónica de uniformização do sentido. Era o que talvez intuía François Rabelais na enigmática fábula das palavras geladas (Quart Livre, LV-LVI) quando nos relata o assombro desses navegantes ao chegarem a uma terra longínqua onde os rigores do inverno congelaram as palavras pronunciadas durante uma terrível batalha. Com a primavera, as palavras derretam progressivamente e os sons, ganhando vida uns a seguir aos outros, começam a articular-se ${ }^{69}$, dando-se a conhecer naquilo que têm de melodioso, mas também na sua aspereza e dimensão incómoda e

Trimodum est lectionis genus: docentis, discentis, vel per se inspicientis. Dicimus enim 'lego librum illi,' et 'lego librum ab illo,' et 'lego librum.' in lectione maxime consideranda sunt ordo et modus".

${ }^{67}$ RICEEUR, P. - Soi-même comme un Autre. Paris: Seuil, 1990.

${ }^{68}$ Ideia longamente explorada por B. Clément em La Voix vertical.

69 "Le Pillot feist responce: 'Seigneur, de rien ne vous effrayer. Icy est le confin de la mer glaciale, sus laquelle feut, au commencement de l'hyver dernier passé, grosse et felonne bataille, entre les Arispamiens et les Nephelibates. Lors gelerent en l'air les parolles et crys des homes et femmes, les chaplis des masses, les hurtys des harnois, des bardes, les hannissements des chevaulx et tout aultre effroy de combat. A ceste heure la rigueur de l'hyver passée, advenente le serenité et temperie du bon temps, elles fondent et sont ouyes"” (Le Quart Livre des Faicts et Dicts Herö̈ques du Bon Pantagruel, LVI, p. 206. in JOURDA, P. (ed.) - Cuvres Complètes. T.II. Paris: Garnier Frères, 1962, p. 206).

Medievalísta online $N^{\circ} 19 \mid$ Janeiro - Junho 2016 (C) IEM - Instituto de Estudos Medievais 29 
desestruturante. A passagem da fixidez material da palavra (emblema da escrita na era da tipografia?) à fluidez sonora (emblema da experiência oral) nunca está isenta de riscos, implicando sempre - pelo menos para o ouvinte - um salto para o desconhecido, o espanto do(s) sentido(s). Era o que também já intuíra Paul Zumthor ao afirmar ${ }^{70}$ que a performance oral altera profundamente o estatuto dos signos que compõem a obra medieval tendendo a "despojá-lo, esse signo, do arbitrário que comporta; a motivá-lo pela presença desse corpo de que emana”. Nesta perspetiva, será que, ontem como hoje, a significação de um texto apenas se consuma plenamente quando incarna num corpo e numa voz que o anima e o faz estremecer? Seja como for, apenas a leitura em voz alta permite ao texto atualizar-se numa temporalidade irreversível que o inscreve numa história de vida, também ela, irrepetível, bem como num espaço concreto e tangível graças ao qual a experiência poética se transforma em verdadeiro lugar comum da memória e do (re)conhecimento ${ }^{71}$.

Na Idade Média como hoje, a leitura em voz alta convida-nos assim a desconstruir uma imagem estereotipada, e algo romântica ou etérea, da narrativa literária enquanto forma ontologicamente cristalizada e pura, perfeitamente acabada e fechada sobre si própria, para nela vermos, antes de mais, uma obra aberta ou uma estrutura ausente (de acordo com a terminologia de Umberto Eco), em perpétuo devir, incessantemente reconfigurada pela voz singular que dela se apropria e que, com ela, se transforma numa dinâmica centrípeta que implica e afeta os próprios ouvintes. Implicando, como vimos, uma copresença e uma experiência partilhada que criam ou reforçam, no seio de uma dada comunidade textual, os laços identitários, a voz envolve finalmente o olhar e o rosto. Ora, através do olhar e do rosto, na sua nudez, fragilidade e exposição radicais, bem como nas emoções que deixa transparecer, será que a leitura em voz alta não nos vem colocar perante a imensa, e cada vez mais urgente, problemática da

${ }^{70}$ La Lettre et la voix, op. cit., p. 21.

${ }^{71}$ Sobre a indissociável relação entre espaço e construção da memória, ver YATES, F. - The Art of Memory. Chicago: University of Chicago Press, 1966, bem como os conhecidos trabalhos de CARRUTHERS, M. - The Book of Memory: A Study of Memory in Medieval Culture. Nova Iorque: Cambridge University Press, 1990. 
responsabilidade por outrem ${ }^{72}$, e, por conseguinte, perante a própria dimensão ética da literatura?

Verticalidade do rosto, verticalidade da voz, verticalidade da leitura: numa das suas últimas crónicas publicadas na revista Visão ${ }^{73}$, Gonçalo M. Tavares afirmava que "ler uma mensagem ou uma frase que não desaparece é para leitores preguiçosos", deplorando que, por oposição aos primeiros leitores dos efémeros sinais inscritos no céu, as pessoas agora leiam de cima para baixo e, estando "o texto [...] abaixo do pescoço [...], isso transforma-o logo num texto inofensivo". Neste sentido, incentivar a leitura em voz alta no âmbito de uma ampla tradição centrada na transcendência da voz, torna-se simultaneamente uma forma de devolver ao texto a sua natureza numinosa, inquietante e desestabilizadora, e de "recuperar o tamanho certo do humano: voltar a ler de baixo para cima"; voltar, em suma, a olhar para o céu.

\section{Fontes}

ADENET LE ROI - Ed. A. Henry. Genebra: Droz, 1982.

AGOSTINHO DE HIPONA - Confessiones. Ed. bilingue (Latim/Francês) de P. de Labriolle. Vol. 1. Paris: Les Belles Lettres, 1977.

AIOL. Ed. J. Normand e G. Raynaud. Paris: Didot, Société des Anciens Textes Français, $7,1877$.

BENOIT (SAINT) - Règle de saint Benoît. Ed. bilingue (Latim/Francês) de H. Rochais. Paris: Desclée de Brouwer, 1997.

BRUNETTO LATINI - Li livres dou tresor. Ed. crítica F. J. Carmody. Genebra: Slatkine, 1998.

CHRETIEN DE TROYES - Romans. Paris: Librairie Générale Française, 1994.

DANTE ALIGHIERI - Divina Comédia. Ed. bilingue de V. Graça Moura. Lisboa: Bertrand, 1995.

\footnotetext{
${ }^{72}$ Penso aqui naturalmente nas reflexões do filósofo E. Lévinas no diálogo Ética e Infinito publicado em 1982 (Trad. portuguesa de J. GAMA. Lisboa: Edições 70, 1988, pp. 75-93).

${ }^{73} \mathrm{~N}^{\circ} 1149$ de 12 de março de 2015, p. 11.
} 
DU BELLAY. J. - Défense et illustration de la langue française. Ed. S. de Sacy. Paris: NRF-Gallimard, 1975.

FROISSARD, J. - Espinette amoureuse. Ed. A. Fourrier. Paris: Klincksieck, 1972.

GUILLAUME DE MACHAUT - Le Livre $d u$ voir-dit. Ed. P. IMBS. Paris: Librairie Générale Française, col. "Lettres Gothiques”, 1999.

HUGO DE SÃO VÍTOR - Hugonis de Sancto Victore Didascalicon de Studio Legendi. Ed. crítica de Ch. H. Buttimer. Washington: The Catholic University Press, 1939. - L’Art de lire. Didascalicon. Trad. Francesa de M. Lemoine.

Paris: Cerf, 1991.

ISIDORO DE SEVILHA - Etimologias. 2 vols. Ed. Bilingue (Latim/Espanhol) de J. Oroz Reta e M. A. Marcos Casquero. Madrid: BAC, 1982.

JACQUES DE VITRY - Histoire de l'Occident (Historia occidentalis). Trad. Francesa de G. Duchet-Suchaux, com introdução e notas de J. Longère. Paris: les Éditions du Cerf, 1997.

JEHAN BODEL - Chanson des Saisnes. Ed. A. Brasseur. Genebra: Droz, 1989.

TRISTAN DE NANTEUIL. Ed. K. V. Sinclair. Assen: Van Gorcum \& Comp., 1971.

LA CHANSON D’ANTIOCHE - Ed. S. Duparc-Quioc. Paris: Librairie Orientaliste Paul Geuthner, 1977.

LA CHEVALERIE VIVIEN. Ed. D. McMillan. 2 vols. Aix-en-Provence: Université de Provence [sénéfiance, 39-40], 1997.

LA PRISE D’ORANGE. Ed. Cl. Régnier. Paris: Klincksieck, 1986.

LE MONIAGE GUILLAUME. Ed. N. Andrieux-Reix. Paris: Champion, 2003.

PHILIPPE DE BEAUMANOIR - Euvres complètes de Philippe de Beaumanoir. Ed. H. Suchier. Paris: Société des Anciens Textes Français, 1984-85.

RABELAIS, F. - Le Quart Livre des Faicts et Dicts Herö̈ques du Bon Pantagruel. in Cuvres Complètes. Ed. P. Jourda. Paris: Garnier Frères, 1962. - Pantagruel. Ed. Guy Dermeson. Paris: Seuil, 1997.

RENAUT DE MONTAUBAN - Ed. J. THOMAS. Genebra: Droz, 1989

ROBERT DE BORON - Merlin. Ed. A. MICHA. Genebra: Droz, 1979.

REGNIER-BOHLER, D. (dir.) - La Légende arthurienne. Le Graal et la Table Ronde. Paris: Robert Laffont, 1989.

ROUSSSEAU, J.-J. - L'Émile ou de l'Éducation. Paris: Garnier-Flammarion, 1961.

Medievalista online $\mathrm{N}^{\circ}$ 19| Janeiro - Junho 2016 @ IEM - Instituto de Estudos Medievais 32 
TOMAS DE AQUINO - Summa Theologicae. Ed. Bilingue (Latim/Espanhol) de S.

Ramirez, t. II. Madrid: La Editorial Católica, BAC, 1959.

\section{Estudos}

BEDOS-REZAK, B. M. ; IOGNA-PRAT, D. - L'Individu au Moyen Age. Paris: Aubier, 2005 .

BIET, C. - "L'oral et l'écrit". in DARMON, J.-Ch.; DELON, M. - Histoire de la France littéraire. Classicismes : XVII ${ }^{e}$-XVIII siècle. Paris: PUF, 2006, pp. 409-434.

BOUTET, D. - La Chanson de geste: forme et signification d'une écriture épique du Moyen Âge. Paris: PUF, 1993.

- "L'oral et l'ecrit dans la France médiévale". in F. LESTRINGANT; M.

ZINK (dir.) - Histoire de la France littéraire. Naissances, Renaissances: Moyen ÂgeXVI siècle. Paris: PUF, 2006, pp. 193-212.

CARRUTHERS, M. - The Book of Memory: A Study of Memory in Medieval Culture.

Nova York: Cambridge University Press, 1990.

CERQUIGLINI, B. - Éloge de la variante. Histoire critique de la philologie. Paris: Seuil, 1989.

CERQUIGLINI-TOULET, J. - "La scène de la lecture dans l'œuvre littéraire au Moyen Âge”. in BOHLER, D. (dir.) - Le Goût du lecteur à la fin du Moyen Âge. Paris: Léopard d'Or, 11, 2006, pp. 13-26.

CERTEAU, M. de - L'Invention du quotidien, 1. Paris: Gallimard, 1990.

CHARTIER, $\mathrm{R}$ - Culture écrite et société. L'ordre des livres (XIV'-XVIII siècle). Paris: Albin Michel, 1996.

CLAMOTE CARRETO, C. - 'Contez vous qui savez de nombre'. Imaginaire marchand et économie du récit au Moyen Âge. Paris: Champion, 2014.

“Topique et utopie du livre au Moyen Âge: le texte (im)possible”. in MILON, A. ; PERELMAN, M. (dir.) - Le Livre et ses espaces. Paris: Presses Universitaires de Paris 10, 2007, pp. 35-61.

CLEMENT. C. - La Voix verticale. Paris: Belin, 2012.

DERRIDA, J. - De la Grammatologie. Paris: Les Éditions de Minuit, 1967. L'Écriture et la Différence. Paris : Seuil, 1967. 
EISENSTEIN, E. - The Printing Press as Agent of Change. 2 vols. Cambridge: Cambridge University Press, 1979.

GALDERISI, Cl. - "Vers et prose au Moyen Âge". in LESTRINGANT, F.; ZINK, M. (dir.) - Histoire de la France littéraire. Naissances, Renaissances. Paris: PUF, 2006, pp. 745-766.

GOODY, J. - The Power of the Written Tradition. Washington/ Londres: Smithsonian Institution Press, 2000.

GREEN, D. H. - Women Readers in the Middle Ages. Cambridge: Cambridge University Press, 2007.

HASENOHR, G. - "Le livre manuscrit". in LESTRINGANT, M.; ZINK, M. (dir.) Histoire de la France Littéraire. Naissances, Renaissances: Moyen Âge-XVI siècle. Paris: PUF, 2006, pp. 151-173.

HAUG, H. - Fonctions et pratiques de la lecture à la fin du Moyen Âge. Approche socio-littéraire du discours sur la lecture en milieu curial d'après les sources narratives françaises et bourguignonnes [1360-1480]). Lovaina, 2013. Tese de Doutoramento apresentada à Universidade Católica de Lovaina.

JANNERET, M. - "La littérature et la voix: attraits et mirages de l'oral au XVI siècle". in KRAUS, D. - “Appropriation et pratiques de la lecture”, Labyrinthe [Em linha]. 3 (1999) [Consultado a 24 de março de 2015]. Disponível em www.http://labyrinthe.revues.org/56

LE GOFF, J. - Faut-il vraiment découper l'histoire en tranches. Paris: Seuil, 2014.

LEMOS, A. - "O Livro de Horas de D. Duarte. Estado da arte, percurso e caracterização de um manuscrito". in BARREIRA, C. e METELO DE SEIXAS, M. (dir.) - D. Duarte e a sua época: arte, cultura, poder e espiritualidade. Lisboa: FCSH/IEM, 2014, pp. 211-239.

LESTRINGANT, F.; ZINK, M. (dir.) - Histoire de la France Littéraire. Naissances, Renaissances: Moyen Âge-XVI siècle. Paris: PUF, 2006, pp. 212-233.

LEVINAS, E. - Ética e Infinito. Trad. portuguesa de J. Gama. Lisboa: Edições 70, 1988.

MANGUEL, A. - Une histoire de la lecture. Paris: Actes du Sud, 1998.

MATTOSO, J. - Poderes invisível. O imaginário medieval. Lisboa: Círculo de Leitores, 2013

Medievalista online № 19| Janeiro - Junho 2016 @ IEM - Instituto de Estudos Medievais 34 
METELO DE SEIXAS, M.; GALVÃO-TELLES, J. B. - "Elementos de uma cultura dinástica e visual: os sinais heráldicos e emblemáticos do rei D. Duarte". in BARREIRA, C. e METELO DE SEIXAS, M. (dir.) - D. Duarte e a sua época: arte, cultura, poder e espiritualidade. Lisboa: FCSH/IEM, 2014, pp. 257-283.

ONG, W. - Orality and Literacy: The Technologizing of the World. Londres/Nova York: Methuen, 1982.

PETRUCCI, A. - "Lire au Moyen Âge”. in Mélange de l'École française de Rome. T. 96. 2 (1984) pp. 603-616.

RICCEUR, P. - Soi-même comme un Autre. Paris: Seuil, 1990.

RUDDER, O. de - "Pour une histoire de la lecture". Médiévales. 3 (1983) pp. 97-110.

SAENGER, P. - "Silent Reading: Its Impact one Late Medieval Script and Society". Viator. 13 (1982) pp. 367-414.

SCHAEFFER, J.-M. - Petite écologie des études littéraires. Pourquoi et comment étudier la littérature ? Vincennes: Éditions Thierry Marchaisse, 2011.

SEGUY, M. - Les Romans du Graal ou le signe imaginé. Paris: Champion, 2001.

STOCK, B. - The Implications of Literacy. Written Language and Models of Interpretation in the Eleventh and Twelfth Centuries. Princeton: Princeton University, 1983.

VANDENDORPE, C. - Du papyrus à l'hypertexte. Essai sur les mutations du texte et de la lecture. Paris: La Découverte, 1999.

VAN HEMELRYCK, T. - "Du livre lu au livre écrit. La lecture et la construction de l'identité auctoriale à la fin du Moyen Âge", in HERMAND, X., RENARD, E. e VAN HOOREBEECK, C. (dir.) - Lecteurs, lectures et groupes sociaux au Moyen Âge. Turnhout: Brepols, 2010, pp. 185-194.

YATES, F. - The Art of Memory. Chicago: University of Chicago Press, 1966.

ZUMTHOR, P. - Introduction à la poésie orale. Paris: Seuil, 1983. - La Lettre et la voix. De la «littérature» médiévale. Paris: Seuil, 1987. 


\section{COMO CITAR ESTE ARTIGO}

\section{Referência electrónica:}

CARRETO, Carlos F. Clamote - "A voz ou a plenitude do texto. Performance oral, práticas de leitura e identidade literária no Ocidente medieval”.

Medievalista [Em linha]. №19 (Janeiro - Junho 2016). [Consultado dd.mm.aaaa]. Disponível em

http://www2.fcsh.unl.pt/iem/medievalista/MEDIEVALISTA19/carreto1903.html ISSN 1646-740X.

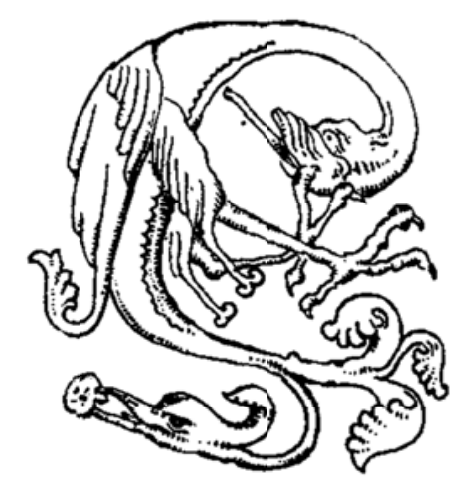

